\title{
Reconsidering the Dual Nature of Property Rights: Personal Property and Capital in the Law and Economics of Property Rights
}

\author{
Enrico Rossi \\ The London School of Economics, Management Department \\ University College London, Computer Science Department
}

June 2020 Draft

\begin{abstract}
In the last two decades, a renewed interest in property rights have challenged the accepted interpretation of property rights as "bundle of rights" over the use of things and have rehabilitated the old classical interpretation of property rights as exclusive (absolute) dominium over things rooted in the right to exclude. This paper provides a three-dimensional framework for the study of property rights and shows that, historically, the reason for this dual nature of property rights derives from the fact that properties can either be treated as personal property, or capital. While the classical approach is consistent with the former interpretation, the neoclassical ("bundle of right") approach is consistent with the latter. By reinterpreting the dual nature of property rights as a dichotomy between capital and personal property the work makes two main contributions to the debates in the legal and economic literature. First, it re-evaluates and justifies the interpretation of property rights as a "politically-embedded" bundle of right provided by legal realist, old progressive and institutional economists at the turn of the twentieth century. Second, it reassesses the conclusions reached by the Coasean legacy in law and economics; the paper shows that transaction costs are necessary and sufficient to explain the emergence and the form of legal institutions only in pure capitalistic societies, but cannot explain the emergence and the nature of legal institutions whenever personal properties are involved. Additional normative assumptions explaining the origin and the legitimacy of value judgments are needed to understand and explain the dual nature of property rights and to make sense of the decisions to employ personal properties as capital (or vice versa). This highlights the often neglected (but decisive) role played by the rationality assumption in legitimizing the normative conclusions reached by Coasean law and economics (and welfare economics more generally). It also highlights that the normative power of transaction costs is always institutiondetermined (socially-embedded), never institution-determining.
\end{abstract}




\section{Contents}

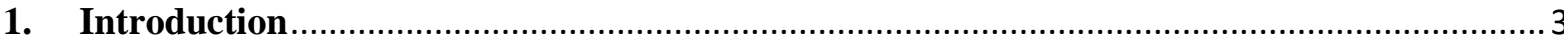

2. Deconstructing classical property rights over personal properties ..................................... 14

2.1. Dualism in ancient and mediaeval property rights: from use to possession ....................... 15

2.2. Modern and classical property rights: the moral significance of possession .......................17

2.3. Classical property rights as exclusive dominium over personal properties ......................... 19

3. Deconstructing neoclassical property rights over capital..................................................... 24

3.1. The relativization (socialization) of capitalistic property rights: inter-dependence in transactions rather than independence of personal actions .....

3.2. The de-physicalization (disintegration) of property rights: contractual economic interests over the use of things rather than physical possession of things .................................................... 30

3.3. $\quad$ Neoclassical property rights as bundle of interests over economic capital .......................... 32

4. From the bundle of right approach to Coasean property right theory ..................................35

4.1. Implications of the bundle of rights approach ....................................................................... 35

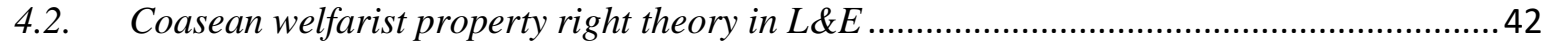

5. Developing a three-dimensional framework for the study of property rights....................... 46

5.1. Setting up a three-dimensional framework for the study of property rights ..........................46

5.2. Classical personal property in three dimensions ............................................................... 50

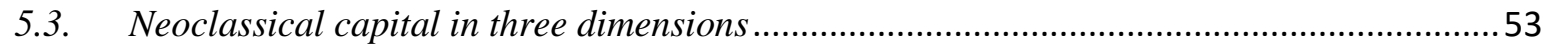

5.4. Outstanding problems with the three-dimensional framework: irreconcilability of the

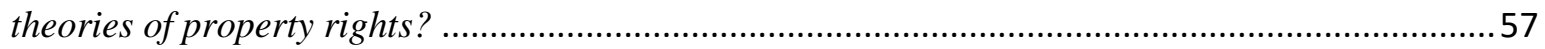

6. Discussion: making sense of the dual nature of property rights..........................................59

6.1. Reassessing the dual nature of property rights in the literature ...........................................59

6.2. Revaluating the realist bundle of right approach in property right theory ........................... 62

6.3. Revaluating the welfarist (Coasean) law and economics of property rights ........................65

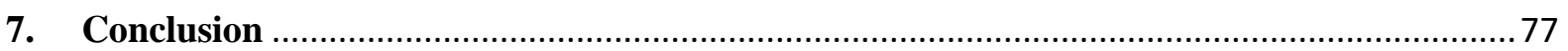

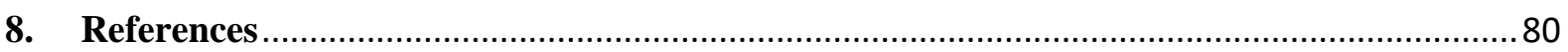




\section{Introduction}

It is an intriguing time to write about property rights. During the last quarter of century our understanding of the concept has been challenged following the breakdown of the consensus among legal and economic scholars on the way in which the concept should be defined, understood and interpreted.

For almost a century legal and economic scholars have broadly agreed on the fact that property rights characterise the set of legal relations among individuals over the use of resources. According to this interpretation, property rights regimes define the mechanisms regulating the way in which alternative claims and interests over the use of resources can be allocated among the various individuals. This is the essence of the so-called "bundle of rights" (or "bundle of sticks") approach that represented the undisputed dominant paradigm in both the legal and the economic discipline for nearly a century, and that is conventionally traced back to the works of Hohfeld $(1913 ; 1917) .{ }^{1}$ This characterization of property rights was in sharp contrast with the earlier classical approach that treated property rights as exclusive dominium of an individual over a thing (the property). ${ }^{2}$

The transition from the old classical approach to the novel bundle of right approach revealed the inherent dual nature of the property right concept, at times undisputed dominium over a thing (regardless of its use), other times interpersonal interests over the valuable uses of a thing (regardless of who controls it). As summarised by Harris (1996: 4): "Property has a dual function, since it governs both the use of things and the allocation of items of social wealth. It is in this duality of function that its controversiality principally resides."

\footnotetext{
${ }^{1}$ But the interpretation of property rights as a bundle of rights is probably much older than that, as noticed by Claeys (2010: 1433-34) and Di Robilant (2013: 878).

${ }^{2}$ In Hohfeld (1913: 21) words: "Sometimes [the word property] is employed to indicate the physical object to which various legal rights, privileges, etc., relate; then again -with far greater discrimination and accuracy- the word is used to denote the legal interest (or aggregate of legal relations) appertaining to such physical object."
} 
It was the "controversiality" and ambiguity of the dual nature of property rights that fostered the breakdown of the general consensus over the bundle of rights approach by the end of the last century in both the legal and the economic discipline. Following the early works of Epstein (1979, 1985), Radin $(1982,1986,1987)$ and, especially, the subsequent contributions of legal philosophers such as Harris (1996), Penner (1996; 1997), Merrill (1998) and Rose (1985), the dominant interpretation of property rights as legal relations was challenged in favour of alternative interpretations of property rights more in line with the older classical paradigm, as an individual's right to enjoy an exclusive and unhampered relationship with a thing vis-à-vis all other members of a society. The common conclusion of these authors was that the bundle of rights' exclusive focus on the mechanisms governing and regulating the allocation of legal interests over the uses of a property, at the expenses of the mechanisms regulating the way in which individuals can acquire and exercise exclusive control (dominium) over properties, cannot satisfactorily capture the essence of property rights and provides an incorrect interpretation of the dual nature of property rights. ${ }^{3}$ By the turn of the century the other aspect of the dual nature of the property concept was brought back into the analysis and regained analytical prominence; property rights started to be defined, once again, in terms of physical possession of, and exclusion from, things.

One of the most interesting and insightful developments of this new course in property law is represented by the information theory of property rights developed by Merrill and Smith (2000, 2001a, 2001b, 2019) and Smith (2002, 2004a, 2004b) that, probably more than any other

\footnotetext{
${ }^{3}$ According to Penner (1997: 71) "the right to property is a right to exclude others from things which is grounded by the interest we have in the use of things". Merrill (1998: 731) summarizes his article by stating that "My claim is simply that in demarcating the line between 'property' and 'nonproperty'... the right to exclude others is a necessary and sufficient condition of identifying the existence of property". While Harris (1996: 124) illustrates how "[t]he person-thing relation can only be dispensed with by representing the decision as a repetitious tautology ... Apart from the perverseness of ignoring the reasons actually invoked in support decisions, such tautological, Hofeldian representation fails to expose questionable normative elements in judicial reasoning."
} 
contribution, has spurred and shaped the current debate over the meaning of property rights in both the legal and economic literature.

Consistent with the conclusions of the Coase theorem, according to the new informational theory the dual nature of property rights emerges as a result of transaction costs, in the same way in which the dual nature of value and costs (and many other economic variables) becomes relevant whenever transaction costs are positive. ${ }^{4}$ While the bundle of right approach would always be the optimal way to define property rights in the ideal case of inexistent transaction costs, exclusion strategies become much more efficient in broadcasting information whenever the cost to define, establish and enforce property rights cannot be neglected: in all those situations where transaction costs cannot be negligible, property rights should be intended as rights to things rooted in possession and based on the right to exclude, consistent with the classical approach. ${ }^{5}$

In line with the comparative institutional approach adopted by standard new-institutional economics (Aoki, 2001; Greif, 1998; Williamson, 1991, 1998), the novel economic approach to property law is at the same time a normative, a predictive, and explanatory theory of comparative property rights regimes, as "[i]t helps explain the structures we do not find, shows how property can be used to maximize option value, and demonstrates why innovation in property takes the institutional paths it does" (Smith, 2012a: 1702).

By rooting fundamental categories of property law into normative law and economics, Merrill and Smith managed to revive the classical approach in property law and to ground its normative

\footnotetext{
${ }^{4}$ One famous example is Stigler's restatement of the Coase theorem in terms of the duality between private and social costs, as "The Coase theorem thus asserts that under perfect competition private and social costs will be equal" (Stigler, 1966: 113). The duality of legal and economic variables has been subsequently reframed in other ways by other authors: as a dichotomy between property and liability rules (Calabresi and Melamed, 1972), as a dichotomy between economic and legal property rights (Barzlel, 1997), or alternatively as a dichotomy between punitive injunctions and compensatory damages.

${ }^{5}$ This informational approach was subsequently reconceptualised by Merrill and Smith as the modular theory of property, or "property as modularity" (Merrill, 2011a; Smith, 2011a, 2011c, 2012a, 2013, 2014a, 2014b, 2017: 150-54): property becomes a standard social interface between actors for the minimization of information costs and the optimization of social welfare.
} 
legitimacy into welfare economics. For this reason, it can rightfully be regarded as a first proper "economic theory of property law" (Smith, 2017). ${ }^{6}$ This has important implications in both economics and property law and challenges established conclusions in both fields.

On the one hand, by explicitly acknowledging the dual nature of property rights, the new information theory challenges the established understanding of property rights in law and economics and Coasean property rights theory. The authors convincingly show that the way in which Coasean and post-Coasean law and economics and property rights theory treat and define property rights (as rights in personam, and therefore as a bundle of interpersonal use rights) is not only analytically incorrect from the point of view of property law, but also logically inconsistent with the main message of Coasean law and economics and with the Coase theorem itself (Lee and Smith, 2012; Merrill and Smith, 2001b, 2011; Smith, 2012a): precisely because the nature and form of legal institutions depend on the level of transaction cost, a correct Coasean analysis should reach the conclusion that, in a world of positive transaction costs, it is optimal (from a social welfare point of view) to define property rights as impersonal rights in rem, consistent with the classical approach (Arruñada, 2003, 2012a, 2016; Lee and Smith, 2012; Merrill \& Smith, 2001b, 2011; Smith, 2012a).

This not only reverses the conclusions originally reached by Calabresi and Melamed (1972) (Smith, 2004b, 2019), but it also has relevant implications for the Coasean legacy in property rights theory more generally (see also Arruñada, 2003, 2012a, 2015, 2016, 2017a).

On the other hand, by anchoring their theory of property rights into the normative assumptions and mechanisms of welfare economics (more specifically, by linking the dual nature of property rights to the duality inherent in the Coase theorem), Merrill and Smith conclude that

\footnotetext{
${ }^{6}$ As recognised by Lueck and Miceli (2007: 187) until recently: "The economics of property rights, however, is well developed but mostly without a focus on property law. The disconnection between the economics of property rights and the economics of property law is longstanding. ... and much of the economics of property rights literature remains ignorant of property law. Similarly, property law scholarship often is ignorant of economics."
} 
the characterization of property rights as "absolute dominium over things" is the only possible normative explanation and justification of property rights that remains neutral and does not endogenously depend on substantive political goals or purposes. ${ }^{7}$ The conflation of structure (or form) with purposes (goals) is often treated as the deleterious legacy of legal realism in property law and is regarded by Smith as one of the most fundamental reasons why the interpretation of property rights as a bundle of malleable legal relations (i.e. rights in personam) cannot be regarded as a satisfactory theory of property rights (Smith, 2009a \& 2009b, 2011b, 2012a: 1716-20, 2012b, 2013, 2014b). ${ }^{8}$

Given its direct challenges to established and accepted conclusions in law and economics, Coasen new-institutional economics, and property law, it is no surprise that the new approach has spurred vibrant debates and controversies among scholars in both the legal literature and the economic literature. The core of the critiques advanced by legal scholars is however quite different from the ones advanced by economists. In fact, they are specular.

Economists debate whether changing the way in which property rights are defined in case of positive transaction costs (as in rem rights to exclude) makes any difference to the substance of the argument or whether it is just a mere semantic and language quibble not worth of too much attention, given that it leaves the Coasean core argument completely untouched (in fact, it reinforces it). ${ }^{9}$ In their view, rights in rem, property rules, and economic property rights are different expressions to convey the same message and characterise the same concept: the individual's "natural" subjective valuation and free choice.

\footnotetext{
7 In Smith's words, "If exclusion is the formal core of the right it is not because it reflects an interest: there is no interest per se in excluding" (Smith, 2013: 330); for this reason, "the right to exclude is not why we have property. Rather, the right to exclude is part of how property works" (Smith, 2012a: 1704).

${ }^{8}$ The same debate in the legal literature, this is also reframed as a means-end problem and has fostered a lot of discussion among legal scholars, especially between progressive and law-and-economics scholars (Alexander, 2009b, 2011, 2014; Claeys, 2010, 2012; Dagan, 2012, 2014a; Katz, 2018; Munzer, 2013; Singer, 2013 \& 2014; Smith, 2009a and 2009b, 2012b, 2013a). ${ }^{9}$ See the two debates in the Journal of Institutional Economics among Hodgson, 2015a, 2015b, Allen, 2015a, Barzel, 2015 and Cole, 2015, and among Arruñada, 2017a and 2017b, Smith 2017b, Allen, 2017, Lueck, 2017, Menard, 2017). See also Munzer (2013) for similar considerations in the legal literature.
} 
The essence of the critiques of many legal scholars is specular. ${ }^{10}$ Legal scholars do not necessarily criticise the theory's separate treatment of the two different types of property regimes. Conversely, many legal scholars criticise the theory's narrow normative foundations and legitimacy, and the employment of a cost-benefit (welfarist) analysis rooted in transaction (information) cost in order to derive conclusions on how the relationships between the two aspects of property rights should be understood and evaluated. In the eyes of many contemporary property scholars, the interpretation of the dual nature of property rights through the lenses of Coasean law and economics provides a very narrow understanding of property rights (as possessory rights to things) that completely overlooks the plurality of goals and heterogeneity of values that property rights promote and serve (see also Hodgson, 2015a \& $2015 b$ for similar considerations).

Moreover, property scholars also stressed that new-property scholars critiques against the normative approach adopted by legal realists may be misplaced and, in any case, too narrow (Claeys, 2012; Dagan, 2013b, 2014; Munzer, 2013).

The very interesting thing is that, although the two sets of critiques to the new economics of property laws take opposite stands, they both defend the bundle of right interpretation of property rights (as a bundle of in personam interests over the use of resources) against the revival of the classical understanding of property rights (as in rem rights to exclude the world

\footnotetext{
${ }^{10}$ The spectrum of the debate in the legal literature is quite broad and diverse, and it is not possible to make justice of the complexity of the argument here. For the sake of simplicity, interesting examples are represented by the debates between new progressives and information scholars in the Cornell Law Review, vol. 94, issue 4 (Alexander et al., 2009; Alexander, 2009a \& 2009b; Peñalver, 2009; Claeys, 2009b; Purdy, 2009; Smith, 2009a; Wyman, 2009; Singer, 2009), and the similar debates ensuing on ends (values or purposes) and means between Smith (2009b; 2012b, 2013a) on the one hand, and Alexander (2011, 2014), Baron (2013), Claeys (2010, 2012), Katz (2018) and Singer (2013, 2014) on the other (but see also Rosser, 2013 \& 2015), while Baron (2009), Rosser (2013), Di Robilant (2013) and Wyman (2017) provide comprehensive overviews of, and further thoughts on, the debate between progressive scholars and law-and-economics scholars in property law, together with the summaries appearing in Claeys (2017: 421-432 \& 2019: 9-16). The reader is also referred to the debate between "exclusiontheorists" and "bundle theorists" in the Econ Journal Watch, vol. 8, issue 3 edited by Klein and Robinson (2011) (Claeys, 2011; Ellikson, 2011; Epstein, 2011; Katz, 2011; Merrill, 2011b; Mossoff, 2011; Munzer, 2011; Penner, 2011; Smith, 2011), and to the contributions to the 2014 conference on the right to exclude provided by Merrill (2014), Dagan (2014b), Ellickson (2014), Savin and Clarke (2014), and Smith(2014a). Similar critiques of the right to exclude are developed in Alexander and Peñalver (2012: 130-155) and Alexander (2018; 182-91), and by Claeys (2009a), Dagan (2012) and Munzer (2013). Dagan $(2003,2011,2013)$ provides an interesting middle ground between the two stands.
} 
from interfering with a thing). This creates a paradoxical puzzle that was already noted by Merrill and Smith (2001b, 2011) and that contributes to the general confusion on the topic that currently remains a mosaic of alternative and often irreconcilable and contradictory interpretative approaches. As summarised by Alexander and Peñalver (2012: xi) in the preface to their textbook, "[t]he field has become the site of major disputes concerning both the conceptual nature of ownership and its normative underpinnings." The remark is still valid today. $^{11}$

The new economics of property law developed by Merrill and Smith, and the debates that ensued, unveil new problems and unclear paradoxes. This begs two questions: how can we make sense of the dual nature of property rights and, second, how can we explain the paradoxes emerging from the specular critiques advanced by both economic and legal scholars?

This paper makes two contributions in this direction and it does so by providing an alternative interpretation of the dual nature of property rights based on a reconstruction of the historical development of the concept.

First, the paper shows that a historical reconstruction of the evolution of the "property right" concept reveals that the dual nature of property rights derives from the fact that properties themselves have a dual nature: the same property can either be employed to fulfil an individual personal needs, and therefore for personal consumption, or it can be employed to fulfil third parties' needs, and therefore as a means of production (and wealth generation) for interpersonal consumption. "Properties" acquire a dual nature as they can almost always perform a dual role: they can be employed as personal properties or they can be employed as capital (also defined as private property).

\footnotetext{
${ }^{11}$ It is sufficient to compare the very different treatments of the right to exclude emerging from the collection of essays edited by Penner and Otsuka (2018), if compared to the collection of essays edited only five years earlier by Penner and Smith (2013), and especially compare the positions expressed by Katz (2018) compared to Smith (2013a), Stern (2018) compared to Ripstein (2013), and Newman (2018) compared to Douglas and McFarlane (2013).
} 
Once that the distinction between personal property and capital is considered, it becomes clear that the dual nature of property right emerged throughout the centuries as a way to make sense of the fundamental changes in the role played by property rights in different economic systems: while the classical understanding of property rights as exclusive dominium over things (rights in rem) is often the only possible and correct way to understand property rights over personal properties in a domestic society, the "neoclassical" understanding of property rights as a bundle of interpersonal interests over the use of resources (rights in personam) is often the only possible and correct way to understand property rights over capital.

Second, by analysing the historical development of the concept the paper also provides a framework for the analysis of the dual nature of property rights and argues that all theories of property rights can be understood along three different dimensions: an ontological (or positive) dimension, an analytical (or methodological) dimension, and a normative (or epistemological) dimension. An analysis of property rights along these three dimensions makes sense of the paradoxes and explains why very similar normative conclusions on the role of property rights may support different positive definitions of property rights (as between the novel informational approach and the standard Coasean approach in law and economics) and, vice versa, why seemingly identical definitions of property rights may lead to opposite normative conclusions (as between the realist and the Coasean bundle approaches). As discussed in the paper, while changes in the ontological and analytical dimensions are necessary to explain the dual nature of property rights and the transition from personal property to capital, different interpretations of the normative dimension ensure that different theories of capital (or personal property) can be formulated and can coexist.

The paper makes various contributions to the current debates over the nature of property rights in both the economic and the legal camp. 
First, in line with the novel developments in property law and law and economics, the paper supports the conclusion that property rights have a dual nature and, as a result, cannot be properly understood using a univocal and monistic definition. Thus, from a positive standpoint, this work supports the argument advanced by contemporary information economists that rights in rem do not merely derive from contract rights (Merrill and Smith, 2001b; Penner, 1997), but they exist independently from the latter as a separate legal concept requiring specific institutional arrangements (Arruñada, 2012a \& 2012b, 2015, 2017a, 2017b).

However, by reinterpreting the dual nature of property rights in light of the distinction between personal property and capital, the conclusions of the paper diverge from the normative conclusions reached by the law and economics of property rights (both new information theory and old Coasean property right theory).

The paper revaluates legal realism and supports its conclusions with respect to the meaning of property rights in a capitalistic society. Legal realists correctly understood that the classical definition of property rights becomes useless, and often meaningless, in a capitalistic society where properties mediate the relationship between individuals in completely new and different ways: the bundle-of-right approach is much more useful and meaningful to understand property rights in a capitalistic society and economy.

Moreover, the paper also endorses and supports the institutionalists and realists' conclusion that it is not possible to separate the validity of economic theories and meanings of economic concepts from the specific external political and institutional context in which these theories and concepts are developed and applied. As the transition from personal property to capital (and vice versa) is necessarily also determined by changes in the external institutional context (social, legal, and political), all theories of property rights are also necessarily subordinated to certain political and social goals, which support, explain and justify this transition. This 
supports Hodgson's argument and his critiques of new-institutionalist property rights theories (Hodgson, 2009, 2015a, 2015b, 2015c) and, more generally, is in line with the critiques against informational law and economics advanced by contemporary progressives and realists such as Alexander (2009b, 2011), Clayes (2012) and Singer (2014), among many others.

Lastly, the work questions the conclusions of Coasean law and economics with respect to the normative role of transaction costs in explaining the dual nature of property rights. Transaction costs remain necessary and sufficient to make sense of the dual nature of property rights and to explain the divergence between the two types of property regimes (Allen, 2015a, 2015b, 2017; Arruñada, 2017b; Merrill and Smith, 2011) only in a capitalistic society, when one side of the duality is already predetermined, at the expenses of the other. But the transition from a socio-economic system based on personal properties to one based on capitalistic accumulation cannot be explained by transaction costs alone, and further normative assumptions are needed to support the conclusions of Coasean law and economics.

Consistent with recent reviews of the Coase theorem (Medema, 2017) and recent critiques of Coasean property right theories (Hodgson, 2015a \& 2015b, Rossi, 2015), the paper argues that the normative power of transaction costs can only be guaranteed if based on the assumption of actors' rationality, which remains the necessary and sufficient condition to explain differences in the normative dimension of property rights, and to make sure that personal properties can be legitimately treated as capital. While this creates a tight conceptual link between neoclassical rationality and capitalistic system (one implies the other and vice versa), this also means that the assumptions over the rational employment of properties is what really determines the nature of the institutional system, not the level of transaction costs: from a normative standpoint, the role of transaction costs is never institution-determining, but always institutionally-determined. 
The reminder of the paper is structured as follows. Section two provides a historical reconstruction of the three dimensions of classical property right theory (as absolute dominium over things) and decomposes it into its three fundamental characteristics: physicalism of possession (ontological dimension), for the achievement and promotion of the individual's personal qualities and values in use (analytical dimension), justified and legitimised on extrasocial and absolute ground (normative dimension). The section shows that there is an inherent consistency in the way in which these three dimensions combines in classical property right theory: the combination of these three features derives from, and is consistent with, an interpretation of property as personal property, consistent with a pre-capitalistic socioeconomic system.

Section three summarises the historical transition from the classical to the neoclassical bundle of right interpretation of property rights and discusses how the neoclassical bundle of right approach replaced the classical physicalist and absolutist approach in response to the emergence of the capitalistic economy in the mid- $19^{\text {th }}$ century. Differently from properties employed for personal use, physical possession and ownership of capital are often severed; this generates a fragmentation and dispersion of property interests (ontological dimension), which are created through inter-personal transactions by means of contractual arrangements (analytical dimension), and are valued and legitimised on the ground of the economic value (in exchange) generated by these interactions and interpersonal transactions (normative dimension). Even in this case the three dimensions are consistent with each other and create a coherent framework for the study and understanding of property rights in capitalistic systems.

Section four focusses on the normative dimension and clarifies the difference between the old neoclassical interpretation of the bundle of right (realist, progressive and institutionalist) and the new neoclassical interpretation of the bundle of right. The section discusses how the realist and institutionalist "bundle-of-rights" approach to property rights sets the stage for the 
neoclassical revolution in value and distribution: the bundle of right approach perfectly fits the ontological and analytical dimensions adopted by neoclassical economics and, not surprisingly, it emerged as the most natural and most appropriate interpretation of property rights in neoclassical (and therefore Coasean) economics. For this reason, the bundle of right approach can be generically defined as the neoclassical approach to property rights, in opposition to the earlier classical approach, where the term "neoclassical" means that it deals with a capitalistic (rather than domestic) socio-economic system. The section discusses how the only (fundamental) difference between the old realist, progressive and institutionalist schools and neoclassical economic theory (and Coasean economics) lies in their different normative assumptions of property rights (but not in their positive definitions of property): while the former assumed a socially-embedded legitimization of normative value judgments, the latter developed a new socially-disembedded economic theory of value based on new assumptions, usually referred to as the "rationality assumptions".

Section five provides the new three-dimensional framework for the study of property rights in light of the dichotomy between personal property and capital, while section six discusses the implications of the framework and clarifies the role played by rationality and transaction costs in the definition and characterization of the dual nature of property rights along its three core dimensions. Section seven recaps the argument and concludes.

\section{Deconstructing classical property rights over personal properties}

The history of the concept of property right can be reinterpreted in light of the tension between use (usufructuary) rights and possessory rights (usus and abusus): is the legitimacy of the use that confers legitimacy to the claims over something, or it is the legitimacy of the claims over something that confers legitimacy to its use? While in the first case the legitimacy of property claims depend on a preliminary definition and characterization of the legitimate uses (the object 
of analysis of property claims is the use), in the second case the legitimacy of property claims depend on a preliminary verification of the legitimate appropriation and possession of the thing (the object and unit of analysis of property claims is the thing itself).

This dilemma reflects the problems emerging from the dual nature of property rights, which have bothered scholars since ancient times. Answers have swung from one end to the other reflecting a variety of approaches and understanding of the very concept of property right.

\subsection{Dualism in ancient and mediaeval property rights: from use to possession}

Property rights originated from the proper use of a thing among ancient Greek philosophers such as Plato or Aristotle, meaning that the concept of property was subordinated to, and derived from, the right to (properly) use a thing (Philbrick 1938: 697-98). While in Plato the individual had neither priority nor prominence over the society and the legitimacy of property derived from the social legitimacy of its use, in Aristotle the legitimacy of property rights rested on its "proper use" (intended as a natural or rational use).

Departing form the Greek tradition, Roman law shifted the focus of the analysis on the thing rather than the use, and regarded property right as having dominium over a thing, intended as the faculty of an individual of having independent and total control over the objects of the physical world (Bouckaert, 1990: 780-84; Philbrick, 1938; Tuck, 1979: 7-13). ${ }^{12}$ Differently from the right to use, the Roman dominium did not derive from an agreement between independent and private parties. For this reason, dominium was originally not understood as a legal right but as an "active" and a-social faculty (Tuck, 1979: 10): "What mattered was the fact that the defendant exerted a physical control over the good of the dominus" (Bouckaert, 1990: 782).

\footnotetext{
${ }^{12}$ See also Stern (2018) for a discussion on dominium intended as "control", as opposed to use.
} 
The qualitative distinction between the right to use (passive right-duty) and the dominium over a thing (active right) was crystallised in the Roman distinction between bilateral rights in personam occurring between private individuals, and public rights in rem, which one possessed against the world as a result of the relationship with the state or sovereign (Bouckaert, 1990: 782-84; Tuck, 1979: 11-12). While the use of a thing was the object of a right in personam, the possession and complete dominium of the same thing was the object of a right in rem. In Roman law the legitimacy of dominium rested on some fundamental moral principles (the ius naturale), rather than on contingent social principles (the ius civile) (d'Entreves, 2017: 22-35); as a result, it was the moral legitimacy of the dominium over a thing that justified and legitimated its use.

This tension between rights of use and rights to possess and control was particularly evident during the mediaeval age given the problems emerging from the need to nest and harmonize the Germanic feudal system with the pre-existent Roman law. As recently illustrated by some authors, the focus on use remained more prominent in common law, which was mainly influenced by the Germanic law of estates where the feudal fragmentation of legal interests over the same properties required the focus of the law to be on bilateral relations between individuals, and therefore on rights in personam, rather than on possessory interests (Chang \& Smith, 2012 \& 2014; Di Robilant, 2013; Singer, 2009). Conversely, civil law remained faithful to the continental Roman tradition by conceiving property as absolute dominium over things, and therefore as a right in rem. ${ }^{13}$

The debate on whether the right to use (the Roman ius properly said) or dominium (total control) was the "natural" foundation of property rights persisted throughout the entire middle

\footnotetext{
${ }^{13}$ As summarised by Di Robilant (2013: 870), "Civil law systems conceive of property as ownership, as holistic dominion: exclusive, single, indivisible, and different in nature from lesser property interests. By contrast, property in the common law is pluralistic and fragmented, having at its core the estates system and the many ways of carving up lesser property interests, from life estates to defeasible fees and future interests."
} 
age, until the tension was resolved in favour of the latter by the $14^{\text {th }}$ century as a way to address the theological problem over the origin and legitimacy of individuals' liberty and free will: consistent with the earlier Roman tradition, property rights were eventually regarded as the naturally protected sphere where independent individuals can exercise their free will through the appropriation, possession and independent use of the things of the external world at the exclusion of all third parties' interferences (Schneewind, 1998: 17-36; Tuck, 1979: 22-31). More generally, property was conceptualised as the way in which individuals could achieve their self-sovereignty over their own individual spheres vis-à-vis the other two sovereigns operating at "higher normative layers": God and the king (Bouckaert, 1990: 784-89; M. Cohen, 1927; F. S. Cohen, 1954: 371-72; Schneewind, 1998: 17-36).

As a result, in the attempt to link problems in legal theory with problems in political philosophy, moral philosophy and theology, the concept of physical possession and exclusion become intimately interwoven with the concept of property right in the late mediaeval jurisprudence and theology: in mediaeval natural law property rights were not mere rights to use things, but rights to exclusive dominium serving and ensuring an individual's free will (Buckle, 1991: 416), while dominium remained an active or self-regarding right (a faculty) belonging to the realm of moral philosophy, rather than a social right properly said (d'Entreves, 2017: 37-49).

\subsection{Modern and classical property rights: the moral significance of possession}

The rise of liberal natural law in the $17^{\text {th }}$ century, and the subsequent emergence and dominance of classical legal thought starting from the $18^{\text {th }}$ century, formalised the approach already adopted by late middle age thinkers and resolved the tension completely in favour of the Roman understanding of property as a right in rem (Buckle, 1991; Tuck, 1979). Both civil and common law eventually regarded property right as an active and exclusive right over things having moral significance and legitimacy; while use rights were intrinsically social rights and, as such, they had a social origin and were rooted into interpersonal interactions, the legitimacy of property 
rights intended as exclusive dominium had moral (thus a-social) justifications and, as such, they were treated as natural (thus extra-social or pre-social) rights, in perfect continuity with the standard natural law approach to property rights adopted by roman law first, and mediaeval Christian thinkers in turn (Haakonssen \& Knud, 1996: 15-62; Heydt, 2017; Olivecrona, 1974a \& 1974b; Schneewind, 1998: 78-81; Waldron, 2002).

This focus on things and their dominium (possession) was not limited to English natural law. In continental philosophy, both the Kantian and the Hegelian interpretation of property rights focussed on the independent dominion that an individual could exercise over the things of the world and, as a result, both conceptualised the physical possession and control of a thing as the necessary precondition for an individual's fundamental moral qualities, such as autonomy, agency, self-governance and free will (mainly in the case of Kant), or free will, selfdevelopment and personality (mainly in the case of Hegel). ${ }^{14}$ Both closely retrace the original moral justification of property rights in liberal natural law, grounded on individual liberty, independence and equality (Locke, 1967).

As a result, although the contribution of eighteenth/nineteenth century continental philosophy was already free from the Christian and theological influences that still very much informed English liberal (natural) law (Schneewind, 1998), the continental understanding of property rights during the $19^{\text {th }}$ century retained the Christian natural law approach to link physical possession to (and to legitimise it through) the individual's most fundamental moral quality: his free will. The way in which "free will" was intended (and dominium justified) varied among the various authors: liberty and self-preservation in Locke, autonomy and self-governance in Kant, self-development in Hegel.

\footnotetext{
${ }^{14}$ The analysis of possession provided by Kant and Hegel I however more "socialised" than the one provided by Lockean natural law. See for instance Alexander and Penalver (2012: chapters 3 \& 4) or Waldron (1988: 343-389).
} 


\subsection{Classical property rights as exclusive dominium over personal properties}

In sum, from the late middle-age to the establishment of the classical legal thought in the 19th century, property rights were linked to the possession (dominium) of the thing, and they were justified and legitimised mainly on moral ground, based on the extent to which the direct and unhampered control of the thing could guarantee free will and/or promote certain fundamental qualities of the individuals.

All schools of thoughts until the late nineteenth century treated the dominium over things and the moral or natural dimension of property rights (together with a focus on the individual) as two interdependent and necessary sides of the same coin: the focus on the thing and its physical possession and control (dominium) was necessary to explain and justify the existence of some fundamental moral qualities of individuals (identified as their free will, autonomy, liberty, selfsovereignty, equality, self-development, depending on the specific school of thought), while the assumed existence of these same moral qualities represented the ultimate justification for the definition of property rights as exclusive and absolute dominium over things. In other words, the physicalist approach to property rights was justified in function of its moral force in promoting individual qualities and values (its absolute and individual nature), while the existence of some fundamental moral values could be justified through the physicalist understanding of property rights.

This means that in all these approaches the justification and legitimation of the social institution of ownership has to be fund in the specific nature of the relationship between the thing (the object of property) and the subject (the owner of property) possessing, disposing, and using it: the specific moral (or natural) values inherent in the special object-subject relationship (not necessarily the inter-personal social dynamics among subjects) justify and legitimise the institution of property rights. 
As a result, even though different physicalist, absolutist and individualist approaches focus on different moral qualities and moral values of the individual, and they ground the legitimacy of property rights on different aspects of the relationship between the thing and the individual, they all share one common interpretation of the relationship between the property and the individual: individuals have a direct and disintermediated interaction with the thing, which they use directly in order to fulfil their own personal needs, necessities and requirements, and therefore advance their own individual moral qualities and values.

In all these interpretative approaches, it is the employment of things as personal properties that ensures free will (and all its more specific interpretations such as autonomy, self-governance, independence, self-development or liberty) and that provides moral legitimation to individuals' property rights over things. ${ }^{15}$ Stated differently, the moral (normative) legitimacy of property rights in the various approaches spanning from the Roman law to $19^{\text {th }}$ century continental jurisprudence rests on (and is limited to) the employment of properties as personal properties. Starting with Locke, money and interpersonal exchange represent a further (problematic) development of a property regimes, not its original constituent, nor it played any role in the original justification and legitimization of property rights. ${ }^{16}$ This two-stage approach was retained by classical political economists (starting with Adam Smith (1970) until Menger (1981)), the transition from the original treatment of property rights regimes to the analysis of interpersonal interactions has been framed as a transition from the theory of use value to a theory of exchange value (and distribution).

\footnotetext{
15 The understanding of properties as personal properties is also at the core of Locke's "sufficiency limitation" (see Waldron, 1988: 209-225): "no Man but he can have a right to what that is once enjoyed to, at least where there is enough, and as good left in common for others [equality statement] ... If such a consent as that was necessary, Man had starved, notwithstanding the Plenty God had given him." (Locke, 1967: 288).

${ }^{16}$ As asked by Locke (1967: 125) at the end of the chapter on property: "And as different degrees of industry were apt to give men possessions in different proportions, so this invention of money gave them the opportunity to continue and enlarge them. ... What reason could any one have there to enlarge his possessions beyond the use of his family, and a plentiful supply to its consumption, either in what their own industry produced, or they could barter for like perishable, useful commodities with others?" On this, see the debate between Macpherson (2011) and Tully (1980), and the discussion in Waldron (1988: 218241).
} 
It is clear that free will, and all the correlative moral qualities emerging from the employment of properties for an individual's personal use, can only be ensured and logically assumed if and only if the individual (i) has direct possession of, and access to, the thing, and (ii) if he is guaranteed a sphere of personal freedom in deciding how the use of the thing best promotes, protects and advances his moral values unhampered by the interferences of others, and relieved of the consent of (and dependence from) others. The first requirement implies physicalism (property rights based on direct physical possession and appropriation of things), the second implies exclusivity in use and exclusion of external interferences or dependences, also referred to as absolutism (property rights defined as an exclusive sphere of absolute control guaranteed by the right to exclude - Penner' exclusion thesis (Penner, 1997: 68-104)), while the combination of the two is necessary and instrumental to support and guarantee some fundamental moral or natural values of the individual.

In common law, this physicalist and absolutist understanding of property rights culminated with Blackstone's famous definition of property rights as "that sole and despotic dominion which one man claims and exercises over the external things of the world, in total exclusion of the right of any other individual in the universe" (Blackstone, 1825). ${ }^{17}$ Similarly, in civil law the classical physicalist and absolutist turn to property was formalised in the French Code Napoleon (article 54) as "the right of enjoying and disposing of things in the most absolute manner provided that they are not used in a way prohibited by the laws or the statues". While the focus on the "dominion over things", or on the "disposition of things" reveals the physicalist dimension of property rights, the qualification of this physical dominion as "sole and despotic", or "absolute", denotes their absolute and a-social (or extra-social) nature rooted into exclusion and exclusivity in use.

\footnotetext{
${ }^{17}$ Even though Blackstone's position with respect to the use-dominion interplay might have been more nuanced and more complex than it has been usually acknowledged (Rose, 1998).
} 
The normative (natural or moral) legitimacy of these definitions clearly has historically rested on the condition that properties are employed by their respective "domini" for their own personal use, thus as personal properties. The reference to "personal use" for the promotion of moral values or natural qualities is however missing from these famous definitions and so is the possibility to link these physicalist and absolutist definitions of property rights to any specific type, or employment, of property, or to restrict its validity to specific conditions or normative assumptions. This missing dimension can easily generate confusion as it allows physicalists and absolutist definitions of property rights to be extended to any other type of property (such as productive capital) and any type of condition without any check on their legitimacy.

Although the classical approach is usually decomposed into its two main dimension of physicalism and absolutism (Vandevelde, 1980), this may be misleading and hide some extra complexity. It is important to decompose the classical approach to physicalism and absolutism into three dimensions. ${ }^{18}$

First, all classical approaches share a common physicalist understanding of property rights as the "thing" is usually the object of the analysis (rights apply to "things"), while property rights are usually understood in terms of physical possession (of the thing, or property).

Second, the analytical focus of the problem (the locus of analysis) is usually the personal relationship that a single individual has with the thing (the object of property), and property rights are evaluated by looking at the way in which the individual's personal interaction with the thing can address certain problems, generate certain benefits, or promote certain values of the individual itself. In other words, these are usually personality theories of property rights

\footnotetext{
${ }^{18}$ This is tripartite division is especially evident in Locke (1967: 286-308), and also discussed in Waldron (1988: 143-47).
} 
with an analytical focus on the individual-thing interaction (such as the one developed by Radin, 1982; 1996).

Third, the justifications on which the legitimacy of ownership rests (the normative roots of property rights) belong either to the individual's subjective moral sphere or to the natural "moral" order. In this sense, justifications and normative legitimations are pre-social or extrasocial (also referred to as absolute). This third dimension places conditions and constraints on the scope of uses and purposes that legitimises property rights form a normative point of view. Even though absolutism in classical jurisprudence has often supported a vision of property rights as a-social facts rather than social institutions, this does not necessarily have to be the case. The extra-social origin of moral precepts does not imply individualism (Kennedy, 2006: 105-09). Even when the normative justification for property rights belong to the moral or natural sphere, property rights themselves may very well remain social (positive) institutions. ${ }^{19}$ In sum, the overwhelming majority of the schools of thoughts since roman times adopted a very similar (and after all, quite consistent) approach and understanding of property rights as (i) exclusive control (dominion) of a thing, (ii) regarded as a necessary device, means or precondition for the realization of certain foundational moral values or natural qualities (iii) appertaining to the individual qua human being. This generated a theory of personal property where the individual's unhampered (exclusive) control over the physical and natural things of the external world was regarded as the necessary precondition for the realization and fulfilment of these fundamental moral values of the individual, such as free will and moral autonomy, which have been commonly regarded as the necessary precondition for the promotion of some fundamental natural qualities of the individual.

\footnotetext{
${ }^{19}$ For instance, social virtues (or social obligations) theories of property rights may be understood as absolutist theories of property rights where the value and goal of property rights are framed in function of social moral categories characterising the nature of the interpersonal relations among individuals (Alexander, 2009a \& 2018; Alexander and Penalver, 2008; Penalver, 2009; Singer, 2014). This is especially evident in Kantian property right theory.
} 
Inevitably, as the relevance of personal properties declines and the importance of properties employed for productive purposes increases, so does the study of interdependences among individuals become much significant and relevant than the definition of the moral foundations of autonomy, independence and self-governance (preconditions for free will). In other words, while $17^{\text {th }}$ century philosophers had to identify the conditions that could morally justify the independence of individuals and their and legitimise their liberation from the will (and power) of the sovereign (Dunn, 1982), $19^{\text {th }}$ century thinkers had to study the conditions that could morally justify the interdependence (and power relations) between individuals (Cohen, 1927; Cohen, 1954; Horwitz, 1973; Siegel, 1986, 1991; Singer, 1982;). This historical shift from properties as means for individual's independence to properties as means for individuals' interdependence required a change in the way in which properties are conceptualised and property rights are defined.

\section{Deconstructing neoclassical property rights over capital}

As extensively discussed by the legal literature, the combined (but often uncoordinated and inconsistent) contributions of American legal positivists and analytical lawyers (such as Oliver Wendell Holmes and Wesley N. Hohfeld), American progressive and institutional economists (such as Richard T. Ely, John Commons, Robert Hale and Adolf Berle), and American legal realists (such as Karl Llewellyn, Jerome Frank, Roscoe Pound, Morris Cohen and Felix Cohen) provoked a U-turn in American property law. ${ }^{20}$

First, legal positivists (starting with Bentham) and analytical lawyers (such as Justice Oliver Wendell Holmes) challenged the classical subjectivist foundation of legal concepts by shifting the focus of the analysis from the individuals' personal (psychological and moral) sphere to the

\footnotetext{
${ }^{20}$ It is not possible to satisfactorily provide a full account of the literature on the matter. Some references are: Dagan (2013b), Fiorito and Vatiero (2011); Fried (2009); Gilmore (1961), Horwitz (1992), Hodgson (2003), Hovenkamp, (1991), Kalman (2016), Leiter (1997), Schlegel (1978), Siegel (1986 \& 1991), Singer (1982 \& 1988a), White (1972), Wiecek (1998).
} 
objectively ascertainable effects of their actions on the social environment (Horwitz, 1992: 3563; Kennedy, 2006: 103-09). This implied a prominence of facts over moral and subjective will (Cohen, 1935).

Subsequently, the concept of property right was both de-physicalized and socialised (or relativized) (Vandevelde, 1980). On the one hand, following the path-breaking contribution of Hohfeld (1913), property was disintegrated into a bundle of legal interests appertaining to a certain property (Grey, 1980). On the other hand, following the combined contributions of positivists, realist, and institutionalists, it was concluded that if property rights are legal interests, then they must derive their legitimacy from social and interpersonal relations among individuals, not from the isolated and independent relationship between an individual and a thing. In Hohfeld (1913: 21) words, the word property had to be used "to denote the legal interest (or aggregate of legal relations) appertaining to such physical object.” This view was formalised in the First Restatement of property (drafted in 1936), where property rights ceased to be rights to things (in rem) and became "legal relations between persons with respect to a thing", ${ }^{21}$ thus rights in personam with respect to things.

The literature provides exhaustive accounts and discussions of the reasons that motivated this conceptual shift in the interpretation of property rights (Alexander, 1997 \& 1998; Baron, 2013; Berle and Means, 1991; Di Robilant, 2013; Fried, 2009; Horwitz, 1973 \& 1992: chapter 5; Larkin, 2016; Mossoff, 2003; Siegel, 1986 \& 1991; Singer, 1982, 1988b; (Mossoff, 2003); (Singer, 1982); (Singer, 1988b); Smith, 2009b \& 2013a; Wiecek, 1998: chapter 4). Among the various factors, one was anonymously regarded as playing a key role: the historical transition from the agrarian and domestic economy of the early $19^{\text {th }}$ century where properties were mainly used for the satisfaction and fulfilment of the owner's personal needs and necessities in

\footnotetext{
${ }^{21}$ Restatement of the law of property (1936). See also the discussion in (Maloney, 1937).
} 
accordance with its requirements and social status, to the capitalistic economic system characterising the American society in the late nineteenth century, where properties were mainly used for commercial and business purposes in order to provide valuable services to customers by means of economic (or contractual) transactions. In other words, rather than on the role of property as personal property (property for personal consumption), the new course focussed on the role of property as capital (property for third party' consumption) (Cohen, 1927; Hale, 1923; Philbrick, 1938). ${ }^{22}$ The intuition that the meaning of property rights changes with the social context represented the fundamental argument associating legal realists, institutionalists and progressives.

Not surprisingly all main legal scholars responsible for the reconceptualization of property starting with Hohfeld were specialised in commercial law or contract law (see for instance Corbin, 1912 \& 1952; Llewellyn, 1930 \& 1937), not in property law strictly speaking (see also Smith, 2012b \& 2013a: 325-29). The same is true for progressive lawyers and economists such as Ely (1914), Adolf Berle (Berle and Means, 1991), F. S. Cohen (1935), Morris Cohen (1927), John Commons (1893 \& 1924), or Robert Hale (1923): their common analytical focus and interest was to understand and conceptualise the role played by the law in shaping the dynamics of industrial capitalism in the new industrial society; by their own admission, their common intellectual and analytical horizon was the emergent capitalist society and the novel problems emerging from it, they were not interested in conceptualizing the nature of property rights in general or in discussing its philosophical foundations and legitimation.

All these authors understood that the role played by properties and property rights in an industrial society characterised by a capitalistic system is extremely different from the role

\footnotetext{
${ }^{22}$ Here we define capital as those assets or resources that are owned and valued not for their capacity to satisfy personal needs directly through personal consumption, but for their capacity to generate some monetary income or revenue through the satisfaction of third party needs by means of market transactions. For a recent discussion on the meaning of capital see Hodgson (2014).
} 
played by the same concepts in an agrarian society characterised by a domestic economy. The assumptions about property rights made by the pre-capitalistic schools of thought (where properties were treated first and foremost as personal properties ensuring the emancipation, autonomy, independence, and self-development of the individual in a feudal and post-feudal society) necessarily lose their validity when properties change their role and function, and become first and foremost instruments (factors) of production employed for the generation of a monetary income (and not for the satisfaction of personal needs), and contributing to the accumulation of wealth and to the economic growth of a social system. In the language of classical economists (from Adam Smith to Karl Marx, up until Carl Menger) the transition from a regime of properties used for personal consumption to a regime of properties used for social production and interpersonal consumption is characterised as a transition from the theory of value to the theory of money, from mere goods or resources to commodities or, in technical terms, as a transition from value-in-use to value-in-exchange.

Under this changed scenario, both the physicalist and the absolutist (or moral) approach to property rights fall short as neither can adequately capture the new role played by "the new property" (Reich, 1964). If properties cease to be employed in personal consumption by independent individuals, property rights cannot be rooted into individual morality anymore, nor into personal (exclusive) possession, but into the objective evaluations of interpersonal relations among mutually interdependent individuals.

\subsection{The relativization (socialization) of capitalistic property rights: inter-dependence in}

\section{trans-actions rather than independence of personal actions}

The first characteristic of the new socio-economic system is that properties in an industrial society are used as means of production in order to do serve third parties and not as means for the satisfaction of an individual's personal needs. For this reason, the focus of the analysis necessarily becomes the economic interaction or transaction between actors, instead of the 
personal action of the single individual. The focus is therefore on the social and interpersonal dimension of property rights and on the role of property as a tool to achieve certain social goals emerging from the economic interdependency among individuals, rather than on the moral values emerging from the personal relationship between an individual and the things of the external world. In this new social view of property rights, actions become trans-actions, and individual independence becomes individuals' inter-dependence. More correctly, the focus shifts from the individual's dependence on, and power over, the external physical and natural world (individual qua human being among other living beings) to the individuals' dependence on, and power over, the external social world (individual qua social being among other social beings) (Hale, 1923). This is the essence of Cohen's "property as power" (Cohen, 1927: 1114), and is also at the centre of Common's famous treatise on the "legal foundations of capitalism" (Commons, 1924: 28-36 \& 100-134). ${ }^{23}$

These transactions can be either consensual, such as in contract law, or conflictual, as in the case of tort law. In either case, this makes the transaction, intended as a "legal relations between persons with respect to a thing", the real unit of analysis of the legal and economic problem. This new course was very clearly summarised by John R. Commons (1931: 651-652; emphasis in the original):

\begin{abstract}
"These individual actions are really trans-actions instead of either individual behavior or the 'exchange' of commodities. It is this shift from commodities and individuals to transactions and working rules of collective action that marks the transition from the classical and hedonic schools to the institutional schools of economic thinking. The
\end{abstract}

\footnotetext{
${ }^{23}$ Commons (1924:25) frames the distinction in value terms: "For, what is the value of lands, buildings, machinery, commodities, but the value of their expected "uses"? And what are their uses but the uses not yet made but yet to be made of them, either in using them directly or in selling their products for money or other products? One is use-value, the relation of man to nature. The other is exchange-value, the relation of man to man."
} 
shift is a change in the ultimate unit of economic investigation ... But the smallest unit of the institutional economists is a unit of activity —a transaction, with its participants."

In sum, in sharp contrast with the received approach of continental private law, for the American progressive lawyers and economists, "[t]he individual action is participation in bargaining, managing and rationing transactions, which are the ultimate units of economic activity" (Commons, 1931: 648). Under this new perspective, property rights become in personam rights to inter-act and trans-act; they emerge as the outcome of a transaction with other parties, as interpersonal rights to perform activities and services through the use of things.

The switch from the extra-social and absolute moral sphere of the individual that characterised the analytical and normative dimension of pre-capitalistic property law, to the inherently social and relative essence of capitalistic property rights where inter-personal transactions become the new unit of analysis represents the essence of the first revolution of twentieth century property law: the relativization (and socialization) of property. Under the new socio-economic conditions property necessarily becomes an instrument generating social power and interdependences among the members of a society (Cohen, 1927); (Reich, 1964).

In the new relativized approach, property rights cease to be regarded as instruments for the protection and promotion of a-social moral qualities of the single individual, such as liberty, independence, autonomy or self-development, and become instruments to regulate social conflicts and interdependences among members of a society (Dagan \& Heller, 2005; Singer, 1982). In this sense, a relativization of property is also necessarily a "socialization" of property and vice versa; the interpersonal nature of property rights and their dependence on social interactions, such as economic transactions, recast the origin and justification of the concept into positive social science away from moral philosophy, consistent with the approach adopted 
by legal positivism first, and analytical jurisprudence, and legal realism in turn (F. Cohen, 1935, Commons, 1932; see Horwitz, 1992: 153-55). As summarised by Pound (1982: 343-44):

"the identification of private property with liberty or personality generally presupposes that property consists of goods that are objects of purely individual or personal enjoyment. But as modern property is for the most part in the instrumentalities of production, the rights of property are also rights to limit the liberty and personality of others who are dependent on these tools to be productive. Juristically, however, the great argument against metaphysical theories of absolute rights of property is ... that they are futile in that they fail to give use any light as to what is private property under given circumstances."

\subsection{The de-physicalization (disintegration) of property rights: contractual economic}

\section{interests over the use of things rather than physical possession of things}

The second characteristic of the new socio-economic system is strictly linked to the previous one: as the goal of properties in an industrial capitalistic society is not to address the private needs and necessities of their respective owners, but to serve the needs and necessities of third parties by means of bilateral transactions, any intangible financial or legal interest playing a role in the social production process can be defined as a "property". This also means that the concept of "property right" can be extended to ensure the protection and preservation of the economic value that any of these interests would command in an economic transaction in virtue of their contribution to the production process. This is the essence of the second revolution in property law: the de-physicalization (or disintegration) of property rights into a bundle of intangible (and economic valuable) interests.

Many scholars at the turn of the twentieth century stressed the fact that anything of value can be "property" and that the institution of property rights should extend to any intangible valuable 
legal, economic and financial interest. It is famous Hohfeld rejection of the distinction between corporeal and incorporeal interests, as "all legal interests are "incorporeal" (Hohfeld, 1913: 24). The same conclusion is restated by Corbin (1922: 429): "Our concept of property has shifted; incorporeal rights have become property. And finally, 'property' has ceased to describe any res, or object of sense, at all, and has become merely a bundle of legal relation". Commons (1924: 28) distinguishes between intangible property ("the expected beneficial behavior of other people to be obtained by way of expected transactions with them") and incorporeal property ("their expected fulfillment of promises which they have made to us ... this is Capital"), before concluding that "[p]roperty has become intangible and incorporeal."

It is clear that the physicalist interpretation of property rights is perfectly logical (and often necessary) in the case of property devoted to personal use. The only way in which a property owner can effectively use a property for his own personal consumption and in order to directly address his own needs is to gain physical possession of the thing, and to establish a direct relationship with the thing: there can be no personal use of a property without a direct physical engagement with the thing itself in the first place.

At the same time, it is also clear that the assumptions that property rights can only apply to physical things, and that the physical possession of the thing is a fundamental necessary step in order to acquire legitimate property rights over something (Epstein, 1979) become useless and often meaningless in a social system where properties are not used for one's personal benefits, but are used as factors of production in a context where their role is to produce economic value by means of market transactions.

As a result, it is the relativization (or socialization) of property rights that necessarily also requires their de-physicalization (or disintegration). The former establishes the new way in which property rights can emerge: property rights can only emerge as the outcome of an 
interpersonal contractual transactions between actors, thus as bundles of rights in personam over the way in which things are employed. The latter defines the new nature of these property rights as those legal and financial interests granting rights over the economic value generated by the use of these things (in economic or contractual transactions).

The strict symmetry and complementarity of these two aspects of the "new property rights" was very clearly summarised by John Commons (1924: 6-7): “These changes from mechanism to scarcity and thence to working rules as the underlying principles of economics have had a profound effect upon the concept of property, changing that concept from a principle of exclusive holding of physical objects for the owner's private use, into a principle of control of limited resources needed by others for their use and thus into a concept of intangible and incorporeal property arising solely out of rules of law controlling transactions."

\subsection{Neoclassical property rights as bundle of interests over economic capital}

The combined socialization, relativization, and de-physicalization of property rights gave rise to the so-called "bundle of right" approach in property law, according to which property rights are a bundle of in personam (contractual) legal interests over the use of things that have some social (economic) value. This novel approach to property rights replaced the previous personal, absolute, and physicalist interpretation of property rights, respectively.

As extensively discussed by legal scholars during the last two decades (Claeys, 2009a; Dagan, 2003, Di Robilant, 2013; Johnson, 2007; Klein \& Robinson, 2011), this approach was equally adopted by commercial lawyers such as Hohfeld and Corbin, ${ }^{24}$ by progressive legal realists such as Morriss Cohen (Dagan, 2013b, 2014a) ${ }^{25}$ by progressive and institutional economists

\footnotetext{
24 "Property has ceased to describe any res, or object of sense, at all and has become merely a bundle of legal relations-rights, powers, privileges, immunities." (Corbin, 1922: 429).

25 "Whatever technical definition of property we may prefer, we must recognize that a property right is a relation not between an owner and a thing, but between the owner and other individuals in reference to things." (M. R. Cohen, 1927: 12).
} 
such as Ely ${ }^{26}$ and Commons ${ }^{27}$ (see Claeys, 2009a \& 2011, Fiorito and Vatiero, 2011). While the socialization (and relativization) of property can probably mainly be attributed to the influence of legal positivists, analytical lawyers and legal realists, the reconceptualization of property rights as interests with economic significance was carried out by commercial and analytical lawyers such as Hohfeld and Corbin, and institutional economists such as Ely, Commons, and Berle.

More generally, the "bundle of right" approach to property right represented the final result of the combined and uncoordinated contributions of analytical, positivist, progressive, commercial, and realist legal scholars, all united by the common goal to bring the legal discipline (and property law in particular) aligned with the novel economic problems posed by the reality of the new industrial socio-economic system. The new capitalistic system was characterised by the accumulation and concentration of property interests into few economic actors whose goal was not to directly benefit from these properties for their own personal necessities and needs (value-in-use), but to generate monetary wealth in the exercise of their business (value-in-exchange). Under these new conditions the old physicalist and absolutist conceptualization of property rights cannot provide any workable or useful definition, and the approach of lawyers should become the one of the economist, and vice versa. As argued by Berle and Means (1991: 299):

"The economist, approaching the problems growing out of the shifting relationship of property and enterprise which we have examined, must start from a different background and with a set of interests differing essentially from those of the law. His

\footnotetext{
26 "The first fundamental institution in the distribution of wealth is Property ... For we must think of private property not as a single right but as a bundle of rights." (Ely, 1899: 543).

27 "To the popular apprehension, this rigid definition of property seems somewhat arbitrary. At least, from the standpoint of the economist, it is better to recognise all of the elements of legal control over valuable objects as property rights ; but to designate certain of these rights as definite, and the residuum as indefinite. Property is, therefore, not a single absolute right, but a bundle of rights." (Commons, 1893: 92; emphasis in the original).
} 
interest is not primarily in the protection of man in his own, but in the production and distribution of what man desires. He is preoccupied, not with the rights of property, but with the production of wealth and distribution of income. To him property rights are attributes which may be attached to wealth by society and he regards them and their protection, not as the inalienable right of the individual or as an end in themselves, but as a means to a socially desirable end".

In this new scenario, the economic and juristic dimensions of the rules of property shall conflate and support one another (Commons, 1924: chapter 1).

In sum, both progressive and early institutional economists understood that the type of legal problems emerging from the new capitalistic society required a switch to an economic (commercial) understanding of property rights and to an economic approach to assess and determine the value of property interests. On the other hand, realists realised that any normative economic problem is necessarily based on some "maximand" and therefore is necessarily driven by some policy goal, or end.

The logic of the analysis in a capitalistic society is therefore reversed if compared to the logic of a domestic or agrarian society: it is the social legitimacy of the use determined through market transactions that confers legitimacy to property (ownership) claims over something, not the other way around. Rather than resorting to a moral theory of (natural) rights or human nature, it becomes the task of economic analysis to determine what a legitimate use is and what is not.

In the work of Commons (1924), this switch is expressed as a transition from the old classical liberal concept of use value to the concept of exchange value:

"Property is none other than the beneficial exercise of the will in dealing with nature or other persons. But dealings with nature are 'corporeal property' and 'corporeal 
property' has dropped out of sight. The business man is not interested in his corporeal property except as a means to an end and that end is its exchange-value. The right to have this exchange-value is simply the right of access to markets." (Commons, 1924: 28)

"Hence the transition in the meaning of property from the use-value to the exchangevalue of things, and therefore from the producing power that increases use-values to the bargaining power that increases exchange-values, is more than a transition-it is a reversal. The reversal was not at fist important when business was small and weak-it becomes important when Capitalism rules the world." (Commons, 1924: 21)

In the United States, this new course became first clear as early as in the 1850s and 1860s, in the transition from the "vested right" approach adopted by the Marshall Court in the first three decades of the nineteenth century to the "substantive right" approach finally adopted during the Waite Court in the second half of the 19th century (see: Ely, 1999; Horwitz, 1973; Hovenkamp, 1988a, 1991: chapter 1; Kainen, 1982 \& 1993; Mayer, 2009; McCurdy, 1975; Siegel, 1986 \& 1991; Williams, 2010).

\section{From the bundle of right approach to Coasean property right theory}

\subsection{Implications of the bundle of rights approach}

The bundle of rights approach that dominated the legal thought throughout the twentieth century has three direct implications, which derive from the reformulation of the three characteristics of a bundle of rights approach: the de-physicalization, the socialization, and the relativization of property rights. The first two are in positive law and define the implications associated with the object and unit of analysis of property rights, and the level of analysis at which normative value judgments apply. The third defines the way in which the two positive 
dimensions are causally, logically, and epistemologically linked and provides normative legitimacy to their linkage.

First, in the bundle of right approach, value ceases to qualify moral attributes and characteristics of the single individual, and becomes a more "mundane" and immanent evaluation of the alternative property interests held by the various actors. It also became an inter-personal category emerging from interactions or transactions between individuals. This social (inter-personal) and a-moral (relative) understanding of a property interest's value made the economic transaction the new locus of value and the "ultimate unit of economic investigation" in the new theory of value and distribution, in the words of Commons (1931: $652)$.

However, the treatment of the economic transaction as the ultimate unit of economic and legal activity (socialization of property rights), and the replacement of the classical value-in-use with value-in-exchange, univocally links the concept of property rights to the performance of an economic transaction. This relegates the concept of property rights to the background and potentially subordinates the whole discipline of property law to the study of contract law and/or tort law. This makes the very concept of property rights redundant and potentially superfluous. From this, "[i]t seems fair to conclude from a glance at the range of current usages that the specialists who design and manipulate the legal structures of the advanced capitalist economies could easily do without using the term 'property' at all” (Grey, 1980: 73).

This implies that property law ceases to have any meaningful role in pure capitalistic systems, together with the concept of property right itself: in an ideal case where all property rights can be completely reduced to a bundle of legal relations (in personam transactions) over the use of things, the combination of contract and tort law can easily address all property disputes and the field of property law can simply be dismissed altogether: property law could be supplanted by 
an economic analysis of contracts in case of consensual in personam transactions, and by an economic analysis of remedies in tort law in case of conflictual in personam transactions (Penner, 1995: 739-42). This was the logic that lead many realists to conclude that the very concept of "ownership title" should have been abolished and replaced with an analysis of contractual clauses between two transacting parties (Llewellyn, 1937).

Moreover, as both contracts and remedies in tort only emerge within the context of a market transaction (intended as the ultimate units of analysis in the bundle approach), issues in property law in a capitalistic system are always linked to, and necessarily depend on, the performance of (interpersonal) market transactions. This makes the economic analysis of market transactions the natural starting point to any analysis, not just in property law, but in private law in general, consistent with the intuitions of old institutionalists. As a result, the subordination of property law to contract and tort law is just another aspect of the subordination of property rights to the operation of the market mechanism through which property interests are defined, enforced, and exchanged.

The second implication derives from the fact that in the bundle of rights approach property rights can be defined exclusively in function of uses, services, or activities, independently from the definition of, and relations to, the thing (de-physicalization of property). Uses replace things as the new object of property (what property rights apply to and protect). The shift from things to uses also implies a shift in the focus of the analysis from means (the thing) to ends (the uses in which the thing is employed that serve specific purposes) (Claeys, 2009b; Smith, 2009a).

The shift in the focus of the analysis from means (the things) to ends (their uses) certainly frees the property law from its uncomfortable extra-social (transcendental) moral roots and from its subjective dimension, but at the same time it also requires the introduction of some alternative substantive frameworks that could provide an unambiguous and objective answer as to which 
uses are to be deemed as socially desirable and should be pursued, and which ones should be regarded as "socially inferior" and should therefore be discarded; in other words, while the physical possession of a thing can be treated as a mere "agnostic" fact to be verified (Epstein, 1979), uses should be preliminary identified, quantified (evaluated), and compared. This problematic aspect of the bundle approach was particularly stressed by Smith (2004b, 2005, 2009a, 2013a) (see also Claeys, 2010).

Given that property rights are treated as disintegrated (intangible and immaterial) bundles of valuable interests over the use of things, the evaluations of the bilateral transactions through which these property rights are exchanged (and thus the discipline of property law) may simply reduce to an economic analysis of the way in which means (the available things) ought to be allocated to alternative ends (their uses). This may lead to the conclusion that property law (but private law more generally) can simply be intended as the "relationship between ends and scarce means which have alternative uses" (Robbins, 1935: 16).

The discussion of this first two implications shows that a pure bundle of rights approach (where only property rights over capital exist) necessarily reduces property law (and all private law for that matter) to an economic evaluation of (cooperative or conflictual) market transactions performed for the social allocation of available means to alternative ends. In a pure capitalistic social system where property rights are defined in line with the bundle-of-rights approach, property law reduces to the field of (neoclassical) economics. Stated differently, the neoclassical theory of property rights in a capitalistic system becomes a neoclassical theory of exchange value (and distribution). This sounds reasonable and should be expected given that a pure capitalistic system is characterised by the fact that properties are only employed as means of production with the goal to maximise total wealth (theory of exchange value), and associated monetary returns (theory of distribution). 
The only aspect of the new bundle approach that still remains to be defined is the choice of the normative framework legitimizing the assumptions and conclusions of this theory of value and distribution and providing the necessary reference framework for the evaluation and comparison of these uses. In other words, what is needed is a normative legitimization of property rights in a capitalistic system, which could legitimize the definition and enforcement of property rights over properties that are employed as pure capital. This derives from two basic considerations. First, the classical subjective (personal) and moral justification cannot be adduced anymore. Second, the definition of property rights as "ends" necessarily requires some additional substantive judgement by the part of lawyers, judges or policy-makers as to which uses are to be preferred over others and this necessarily leads to a conflation of procedural jurisprudence with substantive policy making. This conflict of attribution between courts and legislators in the evaluation of property rights (intended as bundle of uses) first became evident in the US in the 1880s during the debate over the fair and reasonable level of railway rates (see the Seligman-Taussig debate, Seligman, 1881, Taussig, 1891, Locklin, 1933, and the discussions in Hale, 1922, Hovenkamp, 1988b \& 1989, McCurdy, 1975, Siegel, 1986).

If the positive dimension of the bundle approach commanded wide acceptance among twentieth century "post-classical" thinkers, its normative dimension and implications remained the ultimate source of disagreements. Based on the main interpretations of the nature and origin of value and of its normative foundations and legitimacy three main approaches can be identified advanced by, respectively, social positivism, institutionalism and legal realism,.

First, it is possible to assume, consistent with nineteenth century positivists that it is possible to identify an objective source of social value unaffected by the contingent context and invariant with respect to the specific political leanings of the various actors. In this case, all evaluations have social normative force and their objective validity goes beyond the various contingencies of time and space. This is the case of a-political (or disembedded) normative 
judgments advocated by social positivism: evaluations are objective (because social) but absolute (in the sense that they are independent from the specific context).

Second, it is possible to adopt the position of institutionalists, progressives and mild-legal realists and to argue that it is possible to derive normative conclusions over the optimality or desirability of social arrangements, but that these have only relative validity as they are contingent and dependent on the specific political and moral value framework in force in a determinate context. Progressives and institutionalists argue that it is possible to devise social laws, but these social laws are made and created by men for men to follow them. This is the case of politically-driven (or institutionally embedded) normative judgements: evaluations are objective (because social) but relative (to the political position adopted).

Third, it is possible to adopt the anti-formalist position of the most extreme legal realists and to conclude that no objective value judgment is possible and that everything is a matter of subjective opinions and interpretations in relation to the peculiar contingency of the. This is the position adopted by Karl Llewellyn and Jerome Frank in the 1930s in their purest and most extreme interpretation of legal realism (Dagan, 2013b; Horwitz, 1992: 169-192). In this case, some extra-legal framework is needed in order to ground substantive judicial conclusions in an objective assessment of the various uses. This is the normative approach that has mainly attracted the attention and the critiques of contemporary exclusion theorists even though it is just a minor strand of the bundle of right approach (Dagan, 2014a, Munzer, 2013).

The pure subjectivist position of extreme realist is of no help. The politically-embedded form of social objectivism might allow for the coexistence of a plurality of qualitative and incommensurable values depending on the context, while the causal determinism of pure social positivism is based on a quantitative approach to evaluative problems, and can therefore ensure univocal and unambiguous value judgements independently from the context. 
Some problems of the capitalistic economy, such as the legitimacy of the state police and regulatory power, have historically involved political and moral value judgements linked to social well-being, health and safety (Berger, 1995; Hippler, 1986; Kobach, 1996; Nachbar, 2016; Nichols, 1949). For this reason, these problems have been usually framed using the lenses of social morality or political opportunity, in line with the politically-embedded form of social objectivism.

Other problems, such as the problem of just and fair compensation in the case of eminent domain or regulatory taking, the one of fair and reasonable rates in the case of regulated public services, and the more general topic of fair and just pricing in a market in the case of antitrust proceedings, necessarily require the objective quantification of the economic value of economic or legal interests or, in other words, the computation of the exchange value of these interests. It is precisely in order to address these quantitative problems over the fair and reasonable exchange value of capital that the positivist approach adopted by "pure economic theory" might look appealing and can come to the rescue and emerge as a key tool in legal analysis (Commons, 1924).

From these last considerations, a final, third, implication can be derived: in case neoclassical economic analysis can provide the needed objective and invariant normative framework to weight and compare the various uses and to objectively assess their economic value, the substantive conclusions in legal analysis may become themselves the objective results of pure economic analysis and not of contingent political considerations. In this case, the legal analysis conducted in property law becomes a mere deterministic outcome of objective, immutable (atemporal) and a-political social laws of exchange value and distribution.

In sum, while the two positive dimensions of the bundle approach (de-physicalization or fragmentation and socialization) commanded broad consensus, the normative dimension did 
not. While legal realists, progressive and institutional economists writing at the turn of the twentieth century remained faithful to a theory of (exchange) value that was socially constructed, contingent, and politically-determined, economists writing after the mid-1930s progressively shifted towards a positivist understanding of the normative foundations of the bundle approach to property rights: by the mid of the 20th century the mathematical assumptions of the neoclassical theory of value were developed, and the normative foundations of welfare economics were eventually established (Arrow and Debreu, 1954; Debreu, 1959; Samuelson, 1947; see Blaug, 2003 and Rossi, 2015 for a review and references herein). These assumptions identify the conditions that ensure that value can be treated as exogenous to, and independent from, the specific conditions of the political and social context, ${ }^{28}$ and are commonly referred to as the "rationality conditions", even though they are more technically defined as the monotonicity and the convexity conditions (Mas Colell et al., 1995).

The identification of these conditions also provided the normative foundations for an invariant, socially-given and politically neutral neoclassical theory of property rights. This not only marks the separation of the realist interpretation of the bundle of right approach form the Coasean interpretation of the bundle of rights approach, but it also marks the separation of the old institutionalism from the new institutionalism in law and economics.

\subsection{Coasean welfarist property right theory in $L \& E$}

Given the new normative legitimacy of the positivist approach developed by neoclassical welfare economics, the old realist and institutionalist interpretation of the bundle approach could be reframed in positivistic terms providing a new foundation for the neoclassical theory of property rights. Based on the three implications discussed above, it is easy to see that the realist-institutionalist-progressive reframing of the theory of property rights is perfectly

\footnotetext{
${ }^{28}$ Also reframed as those conditions that ensure the independence of value theory from the theory of distribution (see for instance Garegnani, 1984).
} 
consistent with the neoclassical analysis of welfare economics, and sets the ground for the Coasean theory of property rights. In a sense, contemporary Coasean and post-Coasean law and economics represent the ultimate development of the post-classical "bundle of rights" approach in property right theory.

First of all, as extensively remarked by several authors in the recent years, the Coasean legacy in property right theory (what is sometimes called "old property right approach" (OPRA) (Foss \& Foss, 2001)) defines property rights as a bundle of use rights, certainly not as rights to (possess) things (Allen, 2000; Arruñada, 2016; Harris, 1996: 145-49; Klein and Robinson, 2011; Merrill \& Smith, 2001a, 2001b, 2011; Rossi, 2015). Consistent with the de-physicalised understanding of property adopted by progressive and institutionalist economists at the beginning of the century, property rights in post-Coasean law and economics represent rights of action, or rights to exercise valuable interests and to perform valuable actions in relation to things. As effectively summarised by Lueck \& Miceli (2007: 186) in their comprenensive summary of the state of the field: "We define property rights as the ability (or expected ability) of an economic agent to use an asset." This definition echoes the other well known definitions provided by Allen (2000), Barzel (1997), Demsetz (1967), and Shavell (2009), just to name a few.

Secondly, it is well-known that the unit of analysis of new-institutional economics and postcoasean law and economics in general is the economic transaction between two parties. The whole Coasean legacy is based on the primacy of transactions and on the analysis of failures emerging from the performance of maket transactions. The primacy of the economic transaction, regarded as the basic unit of analysis, is the common element linking old institutionalism, new institutionalism and contemporary transaction cost economics; as clearly stated by (Williamson, 2010): 680): "The unit of analysis in the transaction cost economics 
set-up is the transaction - as recommended by Commons (1932) and as is implicit in Coase (1937, 1960).”

Moreover, implied by the primacy of market transactions, is the focus on the market price emerging from these transactions. In the same way in which realist and institutionalist replaced the classical emphasis on use value with the primacy of the exchenge value of the legal interests transacted, the Coasean legacy understands and defines legal institutions starting from an analysis of the features of the pricing mechanism, and of its failure to univocally reveal, and provide a correct measurement of, the value deriving from the use of properties.

As a result, consistent with the social and interpresonal understanding of property adopted by the bundle-of-rights approach, in both old and new institutionalism the market transaction represents the social (interpersonal) mechanism through which property rights are understood and analysed, while the market price emerigng from this transaction represents the value of these property rights.

Thirdly, the Coasean legacy in law and economics provides a clear example of how the dephysicalised snd interpersonal characterization of property rights necessarily relegates the study of property rights to the background and subsumes property law under the two fileds of private law where value is necessarily an interpersonal category emerging from transactions: tort and contract law. As already remarked by various authors ((Bell \& Parchomovsky, 2004); Merrill and Smith (2001b), the various economic theories of property rights belonging to the OPRA are either economic theories of contracts, or economic theories of tort and remedies. The former interpretation mainly follows Coase's 1937 article on the organization of economic activities. In this respect, it is famous Barzel's assertion that "[a]t the heart of the study of property lies the study of contracts." ((Barzel, 1997): 33). The second interpretation mainly follows Coase's 1960 article on nuisance and the conflictual use of common resources; the 
literature emerging from Calabresi and Melamed (1972) reinterprets property law as a branch of tort law.

The same holds for the new-property rights approach (NPRA), where the economic role and relevance of property rights exclusively and necessarily depend on the presence of incomplete contracts and on the failures (and distorted incentives) that come with it (Hart, 1996; Hart and Moore, 1999; Maskin and Tirole, 1999; Tirole, 1999; Williamson, 2002a \& 2002b).

Fourtly, it is no mistery that both Coasean legacies in contract and tort economics, ${ }^{29}$ and newinstitutional economics more generally, ${ }^{30}$ all develop their conclusions starting from the assumption that the underlying problem to be adressed is the "relationship between ends and scarce means which have alternative uses" (Robbins, 1935: 16), consistent with the basic problem in Paretian welfare economics. The Coasean problem is an allocation problem. In this sense, much of the argument and conclusions of the OPRA can be treated as a restatement or a refinement of the fundamental results and institutions of the basic theorems in Welfare economics (Medema, 2017).

In sum, the Coasean positive analysis of property rights share all the characteristics of the original realist, progressive, and institutionalist positive theory of property rights: they both adopt a de-physicalised and a relational (social or inter-personal) understanding of property rights intended as rights over the use of resources that are rooted into market transactions (either cooperative as for contracts or conflictual in the case of tort) and valued according to their economic value-in-exchange (market price). They both are theories of property rights for a

\footnotetext{
29 "The purpose of this paper is to bridge what appears to be a gap in economic theory between the assumption (made for some purposes) that resources are allocated by means of the price mechanism and the assumption (made for other purposes) that this allocation is dependent on the entrepreneur-co-ordinator. We have to explain the basis on which, in practice, this choice between alternatives is effect." (Coase, 1937: 389). "It is my belief that the failure of economists to reach correct conclusions about the treatment of harmful effects cannot be ascribed simply to a few slips in analysis. It stems from basic defects in the current approach to problems of welfare economics." (Coase, 1960: 42).

${ }^{30}$ See the discussion of the various levels of analysis in (Williamson, 2000).
} 
capitalistic (rather than agrarian and domestic) society. What makes the interpretations of the bundle approach radically different are their normative foundations.

Not only OPRA, but all branches of contemporary law and economics, new-institutional economics, organizational economics and contract economics reject the realist, progressive and early-institutionalist conclusion that value judgements are necessarily relative, contingent, and political. The new strand of the bundle-of-right approach embraces and retains the positivist approach of welfare economics and, more generally, of contemporary (normative) microeconomics.

The social positivism of neoclassical welfare economics derives from its treatment of value as an exogenous and invariant (social) concept, and from its treatment of value theory in function of a set of conditions defining a-spatial and a-temporal rues of optimality. The neoclassical invariant theory of value is used by the Coasean legacy in L\&E to develop an invariant theory of (property) rights. This is the essence of Coase's invariance thesis, and of the Coase theorem more generally (Allen, 2015b; Medema, 2017; Medema and Zerbe, 2000; Merrill and Smith, 2001b, 2011).

\section{Developing a three-dimensional framework for the study of property rights}

\subsection{Setting up a three-dimensional framework for the study of property rights}

From the previous discussion, it is possible to identify three different stages: a first ancient and classical stage (mainly influenced by the Roman understanding of property rights and by Christian natural law) predominant until the second half of the 19th century (1860s/1870s c.ca); a second realist, progressive, and analytical stage predominant from the end of the 19th century until the second half of the 20th century (mainly influenced by the peculiar social issues 
emerging in the nascent American industrial society until the post-war period); and a final third welfarist and positivist stage, predominant starting from the second half of the 20th century and quickly emerging under the influence of the neoclassical revolution in welfare economics occurred at the turn of the 1940s.

There is no single dimension according to which it is possible to identify and distinguish all of them and to make sense of their idiosyncrasies and peculiarities. These three stages are as much historical as they are analytical and epistemological so it is possible to obtain a different recombination of the three stages according to the specific perspective adopted.

\begin{tabular}{|c|c|c|c|c|c|}
\hline Dimension & Description & $\begin{array}{l}\text { Implications } \\
\text { for property } \\
\text { rights theory }\end{array}$ & \multicolumn{3}{|c|}{ The three stages of property right theory } \\
\hline $\begin{array}{l}\text { Analytical } \\
\text { or } \\
\text { Methodological }\end{array}$ & $\begin{array}{l}\text { Level or focus of the } \\
\text { analysis } \\
\text { Unit of analysis } \\
\text { Nature of the } \\
\text { goal/objective to be } \\
\text { assessed \& achieved } \\
\text { [Dependent variable] }\end{array}$ & $\begin{array}{l}\text { How is the value of } \\
\text { property rights regimes } \\
\text { being analytically } \\
\text { assessed: } \\
\text { What is of interest for } \\
\text { the property analysis } \\
\text { \& } \\
\text { What (where) is the } \\
\text { locus of value? }\end{array}$ & $\begin{array}{c}\text { Personal } \\
\text { Individual level } \\
\text { (focus on, and assessment of, } \\
\text { personal variables, } \\
\text { characteristics and qualities of } \\
\text { the single individual: actions of } \\
\text { the single individual) } \\
\text { Use value }\end{array}$ & \multicolumn{2}{|c|}{$\begin{array}{l}\text { (focus on, and assessment of, interpersonal variables, characteristics } \\
\text { and qualities of the social system: interactions or transactions } \\
\text { between individuals) } \\
\text { Exchange value ("welfarist" approaches) }\end{array}$} \\
\hline $\begin{array}{l}\text { Normative } \\
\text { or } \\
\text { Epistemological }\end{array}$ & $\begin{array}{l}\text { Origin and nature of } \\
\text { evaluations and } \\
\text { legitimacy of } \\
\text { decisions/prescriptions } \\
\text { [Assumptions and } \\
\text { conditions ensuring that } \\
\text { normative prescriptions } \\
\text { and value judgments are } \\
\text { legitimate and the } \\
\text { analytical conclusions } \\
\text { justified] }\end{array}$ & $\begin{array}{l}\text { Nature and origin of } \\
\text { value and property } \\
\text { rights: }\end{array}$ & $\begin{array}{l}\text { Absolute \& extra-social moral } \\
\text { qualties \& values } \\
\text { (independent from the social } \\
\text { context) } \\
\text { Extra-social (absolute) } \\
\text { use value }\end{array}$ & $\begin{array}{c}\text { Interpersonal relations \& } \\
\text { economic interests emering from } \\
\text { interdependent (power) relations } \\
\text { between individuals shaped by } \\
\text { the contingent social and } \\
\text { political context } \\
\text { Socially-embedded (relative) } \\
\text { exchange value }\end{array}$ & $\begin{array}{c}\text { Interpersonal relations \& } \\
\text { economic interests emering from } \\
\text { interdependent relations between } \\
\text { individuals driven by socially- } \\
\text { disembedded rules of social } \\
\text { interactions \& resource } \\
\text { allocation } \\
\text { Socially-dismebedded (absolute) } \\
\text { exchange value }\end{array}$ \\
\hline \multirow[t]{3}{*}{$\begin{array}{l}\text { Ontological } \\
\text { or } \\
\text { Positive }\end{array}$} & $\begin{array}{l}\text { Object of property } \\
\text { What property rights } \\
\text { apply to } \\
\text { [Independent variable] }\end{array}$ & $\begin{array}{l}\text { What is valuable } \\
\& \\
\text { What is property }\end{array}$ & $\begin{array}{l}\text { (Direct interaction with) } \\
\text { the thing itself }\end{array}$ & \multicolumn{2}{|c|}{ (Holding interests over) the use of the thing } \\
\hline & & & $\begin{array}{c}\text { Roman law, natural } \\
\text { law, continental law } \\
\text { \& classical } \\
\text { jurisprudence }\end{array}$ & $\begin{array}{l}19^{\text {th }} / 20^{\text {th }} \text { cent. } \\
\text { Realist, institutionalist } \\
\text { \& progressive schools }\end{array}$ & $\begin{array}{l}\text { Neoclassical Coasean } \\
\text { Law \& Economics \& } \\
\text { property rights theory } \\
\text { (OPRA) }\end{array}$ \\
\hline & & & $\begin{array}{l}\text { Classical theories } \\
\text { of personal property }\end{array}$ & $\begin{array}{l}\text { Neoclassical th } \\
\text { (private }\end{array}$ & $\begin{array}{l}\text { eories of capital } \\
\text { property) }\end{array}$ \\
\hline
\end{tabular}

Figure 1 - The three-dimensional taxonomy of theories of property rights 
Table 1 graphically summarises the discussion developed in the previous section and compares the three different "stages" of the development of property rights theory along the three dimensions of property right theory.

The definition of property rights is articulated along three dimensions, representing the three fundamental building blocks along which it is possible to study a theory of property rights. The three stages emerge as different recombinations of these three dimensions. The ontological dimension captures the object of property rights and defines "what is property" (the object of property, or "carrier" of value). The analytical dimension defines the locus of the analytical problem and it captures the way in which the analytical problem is framed and the outcomes assessed; the analytical dimension restricts the scope of the analysis to the specific aspect or phenomena that is of interest for the property rights analysis (or focus of the value analysis: the unit of analysis driving the conclusions of the theory). The normative dimension captures the assumptions that provide the normative foundations of the analysis, legitimize its prescriptions, and justifies its predictions (for the given unit of analysis).

In other words, the normative dimension characterises the assumptions defining the nature of value, how value is conceptualised and therefore why property rights are valuable, the ontological dimension characterises the assumptions on what carries or generates value (what is of value and should be protected and enforced by property rights regimes), and the analytical dimension how or where is value manifested (the locus of value and of the property rights analysis). Stated even differently, the three dimensions define, respectively, what is value (normative), what is of value (ontological), and what is the interest or focus of the value analysis (analytical). 


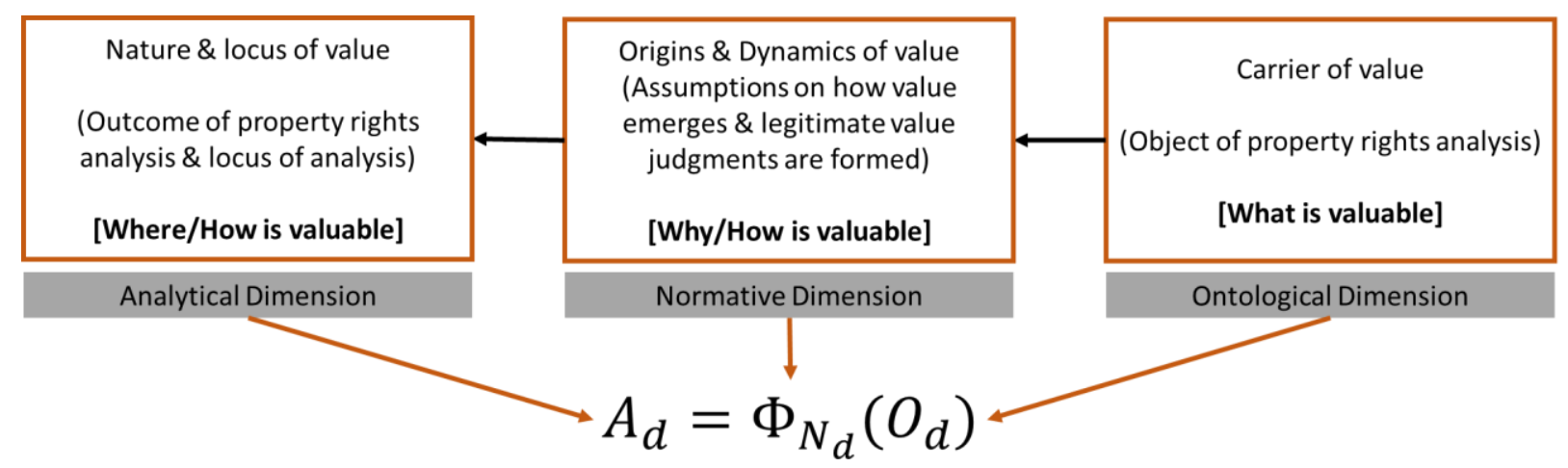

Figure 2 - The logic of the three dimensions of property rights analysis

The dual nature of the ontological dimension (between uses and things) has been historically remarked innumerable times, from ancient and mediaeval thinkers, to Hohfeld (1913) and realists (Cohen, 1935), and has recently regained attention due to the more recent critiques of legal scholars (Epstein, 1979; Radin, 1982; Harris, 1996, Penner, 1997; Smith, 2012a \& 2015). The dual nature of the analytical dimension (between personal and interpersonal locus of value) has also been historically highlighted by Hohfled (1913) and old institutionalists such as Commons (1924, 1931). The ambiguities deriving from the different set of normative assumptions on the nature and origin of value have been usually been discussed by realists (see Horwitz, 1992: chapter 5), old progressive scholars such as Hale (1922), and the new progressive movement such as Alexander (2011, 2014), Dagan (2013a), and Singer (2014) (see Alexander et al., 2009), but they have been completely overlooked by contemporary law and economics (old and new welfarism). The present framework brings all these dimensions together and harmonizes them into a unified three-dimensional taxonomy.

Any recombination of these three dimensions is potentially possible, provided that the framework retains logical consistency and, ultimately, makes sense. The table distinguishes between a classical and a neoclassical approach to property rights based on a specific historical reconstruction of the way in which property rights are defined and their analysis developed. 


\subsection{Classical personal property in three dimensions}

The classical approach defines property rights as exclusive rights (dominium) of an individual over things as this is the natural and consistent way to frame property rights in case: (i) the goal of property rights regimes (and the focus of property right analysis guiding the assessment of property rights regimes) is to protect and promote individuals' ability to have the property at their disposal whenever needed, according to their needs and in line with the contingent necessities (analytical dimension); (ii) given the assumption that the most fundamental value protected by property rights regimes (the needs and necessities justifying and legitimizing their set up and enforcement) is the protection and promotion of the individual's free will (independence, autonomy or self-governance), defined as the ability of the individual to fulfil his necessities and address his personal needs at will, free from interferences of others and independent from the consent of others (normative dimension); (iii) given the assumption that the needs and necessities ensuring and guaranteeing the value of free will can only be addressed and fulfilled through the individual's direct interaction with, and physical possession of, the thing itself, which is therefore regarded as the real "carrier" of value (ontological dimension).

These are three arbitrary ways to intend and conceptualise the various dimensions, deriving from three assumptions concerning the analytical, normative, and ontological dimensions of property rights analysis. Nothing prevents a different combination of these three dimensions, for instance replacing the physicalist ontological assumption with a de-physicalized focus on uses, and assuming that property rights protect and promote other types of moral values (such as equity, solidarity, or happiness). This would require a different set of assumptions along the normative dimension, other than a change in the ontological dimension, but probably not in the analytical dimension (which would still focus on the individual's personal moral sphere). This would still be fine (provided that the analysis retains internal logical consistency), and would 
highlight the most fundamental point that different approaches to property rights require a different "recombination" of the three dimensions along different assumptions.

In any case, there is no doubt that, as argued above, the classical theory of property rights is necessarily a theory of personal property, intended as a theory that defines and characterises property rights over those things that are directly employed by their respective owners (and possessors) for their own personal benefit so that they can autonomously and independently address their own fundamental personal necessities and needs exclusively through the direct use and consumption of the thing, and not through the interaction with, and reliance on, others. This, in turn, ensures, protects and promotes the free will and independence of the individuals. In fact, this is not just a theory of personal property, it is a theory providing the normative foundations (and justifying the legitimacy) of property rights over personal properties: provided that free will and independence is the most fundamental value that has to be promoted and protected (normative assumption), and that this value can only be promoted and protected by making sure that the individual can address and satisfy some fundamental personal natural and moral necessities (analytical dimension) through the direct interaction with, and personal use of, physical things (ontological dimension), property rights have to protect the exclusive and unhampered access and control of certain things so to subtract the individual's needs and necessities (which are necessary to exercise his free will) from the consent and will of others.

At this point, it is important to distinguish necessity from sufficiency.

Here it is argued that there are certain situations and conditions in which properties are employed in personal consumption that necessarily require the classical approach to property rights, and that can only be understood and legitimised if the classical approach to property rights is employed. In these cases, property right theories belonging to the classical tradition become not only the correct, but also the necessary way to frame, understand and legitimise 
property rights. This necessity condition is conditioned to the preliminary knowledge and verification that a certain property is treated as a "personal property" in order to address specific individual needs and protect specific individual values rooted into an individual natural or moral dimensions. This was of course the prevalent (default) state of affairs in any precapitalistic social system mainly founded on self-subsistence and a domestic economy, and still heavily affected by post-feudal legacies.

However, necessity does not imply sufficiency. The previous considerations do not exclude or deny three obvious considerations: first, the fact that even properties employed in personal use can be subject to further characterizations consistent with the bundle-of-right approach; second, that even properties in capitalistic systems may be treated (and protected) as personal properties (not all personal properties in capitalistic system have to be capital); third, the fact that even properties that are prima facie capital can be subject to the protection in line with the classical understanding of property rights. The first consideration retraces Smith (2009a, 2014a, 2014b, 2017) conclusion that exclusion strategies may be a bottom-line (the may represent the "core" of property rights), and that more tailored and fine-tuned governance strategies may be needed "on the top" of exclusion strategies. Similar considerations were developed by Harris (1996). ${ }^{31}$ However, neither Smith nor Harris frame the conditions of necessity and sufficiency in terms of personal property and capital. On the other hand, very similar considerations are developed by Radin's work on property and personhood (1982: 986-88), where she notes that to distinguish personal property from fungible property often makes sense (and becomes necessary), but not always (see also Dyal-Chand, 2013: 713-15).

\footnotetext{
${ }^{31}$ In his duality between trespassory rules and ownership spectrum, Harris (1996: 33) summarises the concept as follows: "We have argued that 'trespassory rules' ... are necessary, but not sufficient, requirement of property institutions ... Yet property institutions also typically comprise, as part of the minimal structure, other varieties of property rules, for which we shall employ the labels 'property-limitation rules', expropriation rules', and 'appropriation rules' ... Property limitation rules and expropriation rules are not strictly necessary requirements of property institutions."
} 


\subsection{Neoclassical capital in three dimensions}

The dual of personal property is capital also defined as "private property" by Marx, or "fungible property" by Radin (1982). As already discussed above, the classical characterization of property rights makes little sense in a capitalistic society and is often unworkable. The most fundamental characteristic of a capitalistic society derives from the different function and role of properties, which are not (exclusively) treated as necessary means for the direct fulfilment and satisfaction of individuals' personal needs, but as instruments for the organization and coordination of social interdependencies among individuals, in the same way in which money is. Capital is property treated as if it was money (employed in economic transactions, with the goal to produce a monetary return and, as a result, increase wealth) (see Hodgson, 2014 \& 2015c: 197-203).

As originally (and correctly) understood by analytical scholars, and subsequently developed by realist, progressive and institutionalists, whenever properties cease to be employed as personal properties and become productive capital, the classical definition of property rights becomes insufficient if not completely useless and nonsensical (Cohen, 1935): property rights over properties used as capital cannot be framed and understood in the same way in which classical theories conceptualised property rights over the use of personal properties. This requires a different interpretation of the three dimensions of property rights.

First, the value of capital derives from its capacity to participate in the production process and to serve needs and necessities of other third parties in exchange for a monetary returns; capital is then valuable if it can generate a stream of income and revenues and increase economic wealth. For its very nature the value of the rights over the use and employment of resources in a capitalistic system is usually quantifiable and objectively measurable in monetary terms. Differently from the classical case of personal property, the value informing the neoclassical 
analysis of property rights in a capitalistic system is based on is not a moral one, but a very mundane one: monetary wealth.

The normative approach adopted by the neoclassical interpretations of property rights can be defined as "welfarist", as the normative legitimacy of the analysis and the justifications for its normative conclusions depend on an assessment of the socially optimal generation and redistribution of wealth. The generation of social wealth in the neoclassical capitalist approach plays the same role that the protection of free will and the promotion of autonomy and independence played for the classical approach. The definition of "optimal" is the crux of the normative dimension, but cannot be defined here as it will depend on the specific normative approach adopted.

Secondly, as properties are used as instruments of production in order to generate a monetary return by serving third parties, it is clear that the locus of the analysis should be the market transaction (or legal relations) between individuals (contractual if consensual, compensatory if conflictual). As the value of a property necessarily emerges through transactions among individuals, the unit of analysis (of capitalistic value theory) is necessarily the transaction, as recognised by both old and new institutionalists (see Williamson, 2000: 599). For this reasons, value in the new system is not only objective and quantifiable in monetary terms, but it also has an inter-personal nature; this requires a shift from use value, emerging from the independent enjoyment of the property as in the classical system, to value-in-exchange, emerging from the employment of the property in an interdependent process of social production ruled by the execution of transactions.

Finally, given the fundamental differences in the normative and analytical dimension, even the ontology of property rights in a capitalistic system is necessarily radically different. On the one hand, as noted by Berle and Means (1991), one of the key features of a capitalistic system is 
the division of the legal ownership of a property from the physical possession and control of the property. This means that the new ontology of property rights cannot be simply based on the physical possession of the thing and cannot depend on the direct interaction of the owner with the thing itself. Possessory rights have very little meanings in the new system and this derives from the fact that the thing is not owned in order to be directly employed by its owner for his own personal benefits. What matters is a capitalistic system are the web of interests over the value of the thing.

On the other hand, as noted by Commons (1924: 24), in a capitalistic systems "intangible and incorporeal properties are more valuable than all physical things" and this means that often there is no identifiable "thing" property rights can refer to. Property rights in a capitalistic system may very well refer to rights over the use of resources, over services provided by these resources, and over intangible interests appertaining to these resources. Given this fragmentation and dephysicalization of the object of the right, neoclassical theories of property rights shift their object of analysis accordingly, as already remarked above.

This has also a further implication, which represents a further fundamental difference with the classical approach to property right theory: pure capitalistic property rights protect ends, not means. Capital is valuable as long as it generates an optimal amount of monetary revenue, which represents the end of the employment of capital, regardless of how the property as means is protected, employed, or controlled. Moreover, as exchange value is an objective and interpersonal (or social) category, the ends defining property rights are also objective and interpersonal, and therefore socially defined.

If all three dimensions are considered, there is no doubt that the novel interpretation of property rights in a capitalistic system provided by legal realist, progressives and old institutionalists at the turn of the twentieth century makes sense, and is perfectly consistent and logically coherent. 
For this reason, capitalistic (in rem) property rights do conflate into contract (in personam) rights and can be derived from them, while it is perfectly consistent to take the ends (uses) as the legitimate object of the analysis, given that the goal of capital is to be employed it in its most lucrative uses in order to maximise economic value. The original definition has to be replaced by a novel (neoclassical) definition of property rights intended as bundles of (economically) valuable interests over the use of resources emerging from the legal relations among individuals.

We call this new theory of capitalistic property rights where properties are treated as capital a neoclassical theory of property rights. Differently from the classical theories of property rights that conceive property as "personal property", neoclassical theories of property rights conceive properties as capital, and define property rights as bundles of (use) rights.

Here, similar remarks on the role of necessity and sufficiency are in order. The claim is that there are certain instances of properties peculiar to capitalistic systems that can only be understood and appreciated if the neoclassical bundle-of-right approach is adopted. In this case, the bundle of right interpretation becomes not only the correct, but also the necessary approach to frame property rights whenever they can only be understood as legal interests over the economic value (monetary return) generated by the employment of a property in a production process. This however does not imply that capital cannot be subject to other forms of protection, such as trespassory and dispossession rules, or that punitive damages do not apply. It also does not follow that the economic (market) value of a personal property cannot also be protected by a property right regime, or that prima facie personal properties cannot be protected according to their potential employment as capital.

As remarked by Harris (1996: 129), the two aspects of the dual nature of property rights are "mutually independent. These twin pillars of property institutions cannot be collapsed either 
one into the other." It is precisely in the relationship between necessity and sufficiency conditions in the interaction between the two interpretations of property (as personal property and capital) that the most problematic aspects of the debate over property right emerge, and where the main insights and implications of the work lie.

\subsection{Outstanding problems with the three-dimensional framework: irreconcilability of the theories of property rights?}

The three-dimensional framework proposed above highlights that any interpretation and recombination of the three dimensions can be conceived, provided that it is logically consistent and coherent. The present work mainly focusses on the duality between the classical approach to personal property and the neoclassical approach to capital because this has historically represented the core of the debate in property right theory, but this does not exclude that other interpretations of property rights can be provided, such as the theories of social virtues, social obligation, and social morality recently developed (Alexander 2009a; 2011; 2014; Alexander and Penalver, 2008; Alexander et al., 2009; Penalver, 2009), property as democracy (Singer, 2014), or human flourishing theories of property rights (Alexander, 2018) (see also Claeys, 2017). All theories rely on their own interpretations of the three dimensions of property rights.

The fundamental question, which at this point still remains unanswered, can be summarised as follows: is it possible to formulate certain assumptions concerning the nature of the three dimensions that not only legitimize the definition of property rights in a specific social system and for a given definition of a property (either personal or capital), but that also explains and justifies the transition in property rights regimes across different normative and social systems, thus providing legitimate normative conclusions on the way in which properties shall be protected by property rights regimes regardless of whether a property is employed for personal use, or as capital? 
In other words, is there a way to reconcile the dual nature of property rights through a framework that is independent from the specific perspective adopted and that can provide legitimate normative conclusions on how we can move from one specific combination of the three dimensions to a different one? This would require a transition from the dual nature of value and property and value to a monistic interpretation of value and property or, in other words, a conflation of use value into exchange value and a univocal mapping of the latter into the former (and vice versa). This would also require that value becomes a univocal and disembedded concept, exogenous to, and independent from, the specific social system considered. The discovery of invariant laws of value, intended as a univocal and monistic category, was precisely the agenda of neoclassical economics starting from the end of the $19^{\text {th }}$ century, and finalised by the mid of the last century.

While realists, progressives and old institutionalists set the stage and provided the analytical and conceptual ground for a neoclassical theory of property rights, the development in (mathematical) welfare economics provided the normative foundations for the Coasean and post-Coasean "new-institutionalist" developments in property rights theory, as discussed above. Thanks to the new normative foundations, and differently from the normative assumptions adopted by the old neoclassical approach to the bundle of right, the new strand of the neoclassical approach could provide new explanatory answers to new normative questions, such as "why economic institutions emerged the way they did and not otherwise" (Arrow, 1987: 734; cited in Williamson, 2000: 596). This is exactly the same remark made by Smith (2012a: 1704) in his critique of the realist bundle of right approach, as opposed to his normative and explanatory "modular theory" of property rights that "explains property's structure, which includes providing some reason why those structures are not otherwise." This type of problem is quite different from the previous ones as it requires a novel framework that could explain 
and justify the transition across institutional settings, not merely explain property rights arrangements within one.

This new normativity depends on specific conditions ensuring the immutable and universal validity of absolute rules of value, which can be assumed independently from the contingent socio-political context; "In other words, we want to explain why universal structures are universal and why we do not find the ones that are universally absent" (Smith, 2012a: 1699). For this reason, there is a radical difference between the socially-embedded theory of exchange value of old neoclassicals such as old realist and institutionalist interpretation of the bundle of right approach, and the socially-disembedded (absolute) theory of exchange value of postworld-war two neoclassicals such as Coaseans and new-institutional economists. The question that still remains to be answered is therefore whether this dis-embedded and cross-dimensional approach is warranted or not.

\section{Discussion: making sense of the dual nature of property rights}

\subsection{Reassessing the dual nature of property rights in the literature}

Differently from the historical approaches (either the classical or the neoclassical ones) that adopted a monistic approach to property rights and did not attempt to reconcile the two, novel approaches recognise that property rights have a dual nature and, as such, they have to be approached from a double perspective. However, to recognise that property rights have a dual nature does not exhaust the problem as there are still various ways in which the dual nature of property rights can been interpreted.

Some authors recognise that both aspects play a fundamental role in the definition of property rights institutions and that they should be treated as two independent but equally relevant pillars (Harris, 1996; see also Alexander, 2014 and Dagan, 2009, 2012, 2013a). This is a case of pure 
ontological dualism that assumes that property rights simultaneously manifest two different and independent aspects. ${ }^{32}$

Other authors such as Penner (1997) recognise that both dimensions of use and exclusion play a role in the definition of property right institutions, but that only one (exclusion) exhaustively and correctly characterises property rights and distinguishes them from other types of rights such as contract rights. This interpretation starts from the recognition that property rights have a dual nature (exclusion and use), but eventually embraces a monistic definition of property rights.

A third set of interpretations recognises the dual nature of property rights and that the two sides are conceptually and logically linked, but concludes that one or the other aspect prevails depending on some external circumstances. This is the typical economic (welfarist) approach that can be found in Calabresi and Melamed's (1972) distinction between liability and property rules, Barzel's (1997) distinction between economic property rights and legal property rights and, finally, Merrill and Smith (2000, 2001a) and Smith (2002, 2004a \& 2004b) distinction between governance and exclusion strategies. All these interpretations explain the dual nature of property rights in function of transaction costs: property rights assume one aspect or the other based on the level of transaction costs characterising a socio-economic system.

The novel contribution of Merrill and Smith to the law and economic literature, was to highlight the fact that property right and contract rights are qualitatively different and cannot be conflated; by doing so, they not only reverse the conclusions reached by Calabresi and Melamed (1972) with respect to the role played by property rules (in rem rights) and liability rules (in personam rights) (Smith, 2004b, 2019), but they also reverse the logic of newinstitutional economists and Coasean law-and-economics: in case of positive transaction costs,

\footnotetext{
32 Or even pluralism, if extended to even other dimensions not developed here (Alexander, 2011, Dagan, 2011: Chapter 3 \& 2013a; Di Robilant, 2013).
} 
centralised institutions (such as in rem property rights) come first, and decentralised arrangements (such as in personam contract rights) follows (Arruñada, 2012b, 2015, 2016, 2017a; Merrill and Smith, 2001b, 2011). In the words of new-institutional economists, this means that in case of positive transaction costs "economic property rights" derive and emerge from "legal property rights" and not vice versa, as the standard Coasean analysis would assume. By breaking down the definition of property right into its three fundamental dimensions, this work proposes yet a different interpretation of the dual nature of property right rooted in the distinction between personal property and capital (also referred to as private property in the narrow sense of the word). This approach retraces Radin's theory of property based on the distinction between personal and fungible property (Radin, 1982, 1987), but it goes beyond the mere problem deriving from the marketability or alienability of a property, by showing how the dual nature of properties is a complex multi-dimensional problem emerging from the interaction of three core dimensions. Beside Radin's notable exception, only few other works have (only recently) discussed property rights in light of the dichotomy between personal and private property, either with reference to the duality (or even plurality) between (personal) value in use and (interpersonal) value in exchange (Alexander, 1998; 2011; Dyal-Chand, 2010; see also the discussion in Rossi, 2015 Singer, 2008 \& 2014), or in relation to the growing literature on the sharing and access economy (Aloni, 2018; Dyal-Chand, 2013; Kreiczer-Levy, 2015, 2017, 2019: chapters 2 \& 7).

The interpretation of the dual nature of property rights in light of the personal-capital dichotomy adds more depth and complexity to the analysis and reveals that the nature of property rights not only depends on the specific conditions of the eternal context (as welfare economists and law and economics scholars recognise), but also on the political and legal context, on the technological context, and, moreover, on the cultural and behavioural attitudes of individuals. For this reason, although the proposed framework internalises and supports 
some core intuitions proposed by the new law and economics of property law (namely, the necessity to sever in personam contract rights from in rem property rights and to treat them as two separate institutional arrangements), it also highlights some problems with the current literature in the law and economics of property rights (new and old) founded on the concept of transaction cost.

Based on the discussion developed above, two main considerations are in order.

\subsection{Revaluating the realist bundle of right approach in property right theory}

First, although the present discussion embraces the renewed focus on the possessory nature of property rights and firmly rejects the monistic interpretation of property rights as mere bundle of interpersonal interests advanced by legal and economic scholars during the first decades of the last century, it nevertheless also indirectly supports the argument of realists, progressive and old institutional economists and completely embraces their original intuitions and conclusions, while disagreeing with the recent critiques moved against them.

First of all, the treatment of a property as a means of production for the generation and increase of overall wealth (capital) directly depends on the specific social, legal and technological context, consistent with the claims made by progressive and institutional economists at the turn of the $20^{\text {th }}$ century (and economists and sociologists such as Marx during the $19^{\text {th }}$ century). On the one hand, technological advancement such as the invention of the steam engine in the $18^{\text {th }}$ century, or the development of internet platforms at the turn of the 21 th century, ensure (for different yet very similar reasons) that properties that could originally only be treated and conceptualised as personal properties can suddenly become capital.

On the other hand, this transition can only be possible as long as the legal setting allows it and the respective owners agree to do so. As a result, whether a property can be conceptualised and treated as "capital" also depends on the specific institutional setting: for instance, the 
development of financial markets and the possibility to collateralise personal properties are necessary ingredients to the emergence of capitalism and, as a result, for the emergence of the dual nature of property rights (Hodgson, 2014, 2015c: 170-72 \& 252-56). This is consistent with the old argument of institutionalists that economic outcomes and economic concepts depend on the specific legal and institutional context and cannot be treated as exogenous rules of a social system.

Secondly, the reinterpretation of the dual nature of property in light of the dichotomy between personal property and capital reveals that the harsh critiques addressed against the realist and progressive movements of the early decades of the $20^{\text {th }}$ century by the part of many contemporary property scholars may be unwarranted and undeserved

Legal realists and analytical jurists at the turn of the $20^{\text {th }}$ century have been recently accused of having used the bundle of right approach to bend property law to specific policy goals and objectives (this critique has been particularly reiterated by Henry Smith, 2009, 2011, 2012b, 2013, 2014b, 2019). According to this critiques, the bundle-of-right approach is particularly problematic as it is an end-based approach to property law that confuses purposes with means and provides an interpretation of property rights as a malleable instrument in the hands of policy makers in order to pursue specific policy goals. As remarked by Smith, this approach has several analytical and epistemological shortcomings, one being the fact that the available use-privileges should be identified, defined, and quantified ex-ante. Conversely, the classical interpretation of property rights as a right to things rooted in physical possession and founded on the in rem right to exclude is to be preferred as it does not reflect any specific substantive (and partisan) interest, so that "[o]ne could say that exclusion is like use-neutral governance" (Smith, 2013a: 331). 
Once that the dual nature of property rights is framed in function of the dualism between personal property and capital (as realists and progressives originally did), it is clear that this critique is well-founded, but only partially so. This critique is certainly spot-on due to the onesided approach adopted by realists and progressives, who exclusively focussed on the pure capitalistic nature of property and completely neglected the importance of possessory rights and the key role played by the "the thing" in the more general and comprehensive understanding of property rights. It is hardly possible to adopt a goal-based approach and to treat property rights exclusively as a mere bundle of (economically) valuable uses whenever individuals are free to employ their property as they like.

However, there is an inherent logical consistency and an undeniable logical correctness in the realist and progressive approach: if only capital is considered in the analysis (an assumption implicit in many realist and progressive works), the focus on ends of the bundle-of-rights approach becomes comprehensible and, in a sense, perfectly legitimate. There is no ambiguity in the way in which capital is employed and in the goal served by capital: by definition, capital is always employed in order to maximise the economic value (monetary returns) deriving from its use.

As a result, while a theory of personal property necessarily requires neutrality in ends and goals and agnosticism in value judgments (free will guaranteed by the "open endedness" of goals represents the essence of property law in the classical tradition), a theory of capital is much less demanding from this point of view and only requires a theory of economic welfare (of value and distribution). This still presents some fundamental theoretical challenges (for instance the trade-off between efficiency and distributive considerations, or fairness and welfare: Kaplov and Shavell, 2003 \& 2009), but it also allows the theorist and analyst to overlook much of the difficult normative problems linked to the requirement of moral and political neutrality in ends and purposes, and to be more specific on the policy assumptions on 
how properties ought to be employed and therefore regulated. Not surprisingly, neoclassical (Coasean) welfare economics has retained the focus on uses and ends that characterises the bundle of rights approach:

\subsection{Revaluating the welfarist (Coasean) law and economics of property rights}

The previous argument leads to the second important set of considerations of the work, which involves the role of behavioural (and therefore moral) considerations in the approach adopted by the law and economics of property rights, and in the validity of its conclusions.

The distinction between personal and capital not only reveals that the nature of properties, and the meaning of property rights, necessarily depend on the specific technological, legal and socio-political context, but it also reveals that they depend on the decisions and the behaviour of individuals, and therefore on the socio-cultural and moral context. Put differently, the transition from personal property to capital occurs whenever the technological context allows it, whenever the owner is able to do so or is in a condition to do so (socio-political context), whenever the owner is allowed to do so (legal context), but also whenever the owner is willing to do so (socio-cultural context).

This can be understood as a problem of necessity and sufficiency in property law: the fact that an individual can treat his property as capital (and use it as an indirect means to generate revenue rather than as a means to use it for his own exclusive benefit) does not imply that he will necessarily do so. In other words, in order to normatively link the two aspects of property and to make sense of its dual nature, not only we need to know the details of the technological, political and legal context, but we also need a theory of individual behaviour (this point was also stressed by Hodgson, 2015a). It is at this point that the Coasean and post-Coasean legacy in law and economics and property right theory becomes problematic and unveils some conceptual difficulties. 
The new informational (or modular) theory of property rights advances a new way to understand and characterise property rights whenever transaction costs are positive, but it retains the standard normative conclusions of Coasean law and economics with respect to the role of transaction costs; as summarised by Allen (2017: 787; emphasis in the original), "[Coase] purpose was to show that positive 'transaction costs' were necessary and sufficient for any understanding of how things like 'legal positions' are allocated."

The "necessity and sufficiency" of positive transaction in the normative definition of property regimes clearly emerges in Merrill and Smith (2011: S94) reformulation of the efficiency and invariance claims of the Coase theorem as a "Coase corollary", which argues that "[i]n a world of zero transaction costs, wealth maximization will occur regardless of the nature and scope of property rights." This is just a different way to conclude that "transaction costs" is regarded as the sole gatekeeper of the dual nature of property rights, and that the two aspects of property rights would necessarily conflate into each other if transaction costs were zero. Stated differently, the conclusion of neoclassical (welfarist) law and economics is that in a world of zero transaction costs it would not matter how property rights regimes are defined and properties employed, as the dual nature of property rights would disappear and the economic result would be independent from the characteristics of the legal institutions (invariance thesis).

This conclusion is accepted by all law and economics scholar, regardless of whether the dual nature is understood as a dichotomy between liability rules and property rules (Calabresi and Melamed, 1972), as a dichotomy between economic property rights and legal property rights (Barzel, 1997), between governance rules and exclusion rules (Smith, 2002, 2004a \& 2004b), between use externalities and exchange externalities (Arrunada, 2017; Smith, 2003), between the "audience of transactors" (definite audience) and the "audience of strangers" (extensive audience) (Merrill, 2011a, 2015a, 2017; Smith, 2003, 2011c), or, more simply, between contract rights in personam and property rights in rem. 
There is no doubt that the presence of positive transaction costs is sufficient to explain the dual nature of property rights: properties cannot be treated as capital if the economic system and the financial market are not sufficiently developed and all monetary opportunities will always be foregone in these situations. The decomposition of the dual nature of property rights into its three core dimensions as outlined above reveals some problems with the necessity condition.

The problem with all Coasean approaches, and with law and economics more generally, derives from the fact that they all start from the normative assumptions stipulated by neoclassical welfare economics that ensure the social disembeddedness of (exchange) value. These assumptions, usually referred to as the "rationality assumptions", represent a normative constraint on the behaviour of individuals (on the shape of their utility surfaces, or on the structure of their preference or opportunity set). The specific purpose of the rationality assumption is to impose a duality condition on the dual nature of the economic problem: utility in use can be expressed in function of monetary costs and returns in exchange, and vice versa (see Rossi, 2015 and references herein; for more technical discussions, see Mass-Colell et al., 1995, and Cornes, 1992). This collapses the two independent dimensions of a problem (personal use and monetary exchange) into one single dimension and, by so doing, it also resolves the dual nature of value.

With the normative dimension out of the way (because fixed by the rationality assumption) the analysis also loses one degree of freedom, and the analysis of the dual nature of property right developed by the welfarist approaches in law and economics becomes the result of a twodimensional framework. In this case, dichotomies along the analytical and the ontological dimension become sufficient to characterise, and makes sense of, the dual nature of property rights. Figure 3 exemplifies the standard way in which a dual approach to property rights is understood and framed by welfarist neoclassical (Coasean) theories of property rights. 


\begin{tabular}{|c|c|c|c|c|}
\hline Dimension & Description & $\begin{array}{l}\text { Implications } \\
\text { for property } \\
\text { rights theory }\end{array}$ & \multicolumn{2}{|c|}{$\begin{array}{l}\text { The dual nature of property rights in the } \\
\text { new economics of property law }\end{array}$} \\
\hline $\begin{array}{l}\text { Analytical } \\
\text { or } \\
\text { Methodological }\end{array}$ & $\begin{array}{l}\text { Level or focus of the } \\
\text { analysis } \\
\text { Unit of analysis } \\
\text { Nature of the } \\
\text { goal/objective to be } \\
\text { assessed \& achieved } \\
\text { [Dependent variable] }\end{array}$ & $\begin{array}{l}\text { How is the value of } \\
\text { property rights regimes } \\
\text { being analytically } \\
\text { assessed: } \\
\text { What is of interest for } \\
\text { the property analysis } \\
\& \\
\text { What (where) is the } \\
\text { locus of value? }\end{array}$ & $\begin{array}{c}\text { Personal } \\
\text { Individual level } \\
\text { (focus on, and assessment of, } \\
\text { personal variables, } \\
\text { characteristics and qualities of } \\
\text { the single individual: actions of } \\
\text { the single individual) } \\
\text { Use value }\end{array}$ & $\begin{array}{c}\text { Inter-personal social level } \\
\text { (focus on, and assessment of, } \\
\text { interpersonal variables, } \\
\text { characteristics and qualities of } \\
\text { the social system: interactions or } \\
\text { transactions between } \\
\text { individuals) } \\
\text { Exchange value ("welfarist" } \\
\text { approaches) }\end{array}$ \\
\hline $\begin{array}{l}\text { Normative } \\
\text { or } \\
\text { Epistemological }\end{array}$ & 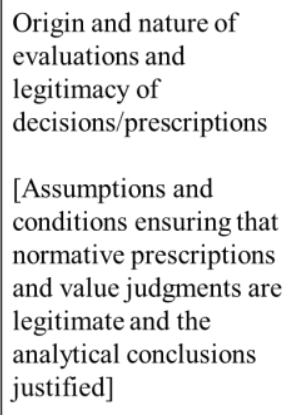 & $\begin{array}{l}\text { Nature and origin of } \\
\text { value and property } \\
\text { rights: } \\
\text { How do legitimate value } \\
\text { judgments emerge } \\
\& \\
\text { How (why) are property } \\
\text { regimes valuable } \\
\text { (legitimate) }\end{array}$ & \multicolumn{2}{|c|}{$\begin{array}{l}\text { Rationality in interpersonal relations driven by socially- } \\
\text { disembedded rules of social interaction \& resource allocation } \\
\text { Socially-dismebedded (absolute) exchange value driven by } \\
\text { neoclassical rationality assumptions }\end{array}$} \\
\hline $\begin{array}{l}\text { Ontological } \\
\text { or } \\
\text { Positive }\end{array}$ & $\begin{array}{l}\text { Object of property } \\
\text { What property rights } \\
\text { apply to } \\
\text { [Independent variable] }\end{array}$ & $\begin{array}{l}\text { What is valuable } \\
\& \\
\text { What is property }\end{array}$ & $\begin{array}{l}\text { (Direct interaction with) } \\
\text { the thing itself }\end{array}$ & $\begin{array}{l}\text { (Holding interests over) the use } \\
\text { of the thing }\end{array}$ \\
\hline & & & $\begin{array}{c}\text { Exclusion / Modularity } \\
\text { Strategy } \\
\text { (Property rules } \\
\text { Extensive audience } \\
\text { Exchange externalities } \\
\text { Rights in rem) }\end{array}$ & $\begin{array}{c}\text { Governance Strategy } \\
\\
\text { (Liability rules } \\
\text { Intensive audience } \\
\text { Use externalities } \\
\text { Rights in personam) }\end{array}$ \\
\hline
\end{tabular}

Figure 3 - The dual nature of property rights in the new economics of property law

The new economics of property law has the undeniable merit of having introduced the classical dimension (the physicalist and exclusionary) of property rights into the analysis. However, the adherence to the normative principles of neoclassical welfare economics renders the framework a "hybrid": it includes the ontological and analytical dimensions of the classical theory of personal property, while evaluating and judging its results and conclusions thought the specific normative assumptions of neoclassical welfare economics. This simplifies the analysis as it 
only leaves one single degree of freedom to the analysis, which can easily be studied and analysed by employing one sole explanatory variable (transaction costs). However, this also creates an inconsistency and unbalance in the framework as the normative (evaluative) dimension characterising the classical theory of personal property is overlooked and lost: the framework cannot account for a plurality of incommensurable and heterogeneous value judgments.

More specifically, in the specific case of a theory of personal use of properties, the monism in value judgment cannot allow for the individual free choices to keep the properties for themselves and to use them for their own exclusive personal consumption. This decision would naturally emerge whenever the use value of the property emerging from the fulfilment of an individual personal needs is kept distinct from, and remains irreconcilable with, the exchange value emerging from the employment of a property as capital.

This should not be problematic or troublesome, as long as it is recognised that the necessity and sufficiency conditions derive from the specific normative assumptions. If all three dimensions are considered and classical property right theory is embraced in its entirety, it should follow that the absence of transaction costs cannot be sufficient, alone, to explain the reasons why all individuals decide to employ their properties as pure capital rather than personal properties. This challenges Merrill and Smith's "Coase corollary" and, more generally, all efficiency claims that elevate transaction costs as the necessary and sufficient explanatory factor of wealth maximization and institutional regimes. The efficiency and invariant results of wealth maximization are in fact achieved if an only if all properties are employed as capital by their owners, and no individual "wastes" (from a welfarist point of view) his property in personal consumption: personal consumption does not generate income and does not increment the social wealth of a system, thus it is suboptimal and should be (normatively) ruled out. 
Moreover, the distinction between personal property and capital also challenges the specular (but different) conclusion that positive transaction costs are necessary and sufficient to understand how legal positions are allocated among individuals (Allen, 2017: 787). Even this "anti-invariance" claim can only be correct under the additional assumptions that all properties are employed as capital and no individual appropriates properties for his own personal benefits. It is clear that as soon as the implicit normative assumption guiding the analysis is relaxed, and the dual nature of properties (and value) is taken into account so that the personal use of properties becomes an incommensurable alternative to the capitalistic use of properties, the mere presence of positive transaction costs becomes uninformative and cannot alone explain the configuration of property rights within a social system: a further condition is always necessarily needed in order to explain to understand why and when individuals decide to derive objective exchange value from their properties rather than subjective use value.

The previous discussion simply highlights the fact that whenever the dual nature of property rights is considered in its totality, and all three dimensions are taken into account, transaction costs alone are neither necessary nor sufficient to derive normative conclusions on how value is generated and properties ought to be protected: some further normative assumption belonging to the moral and cultural sphere that "controls" for the behavioural choices and decisions of the property owners is necessarily needed. This assumption is usually defined as the "rationality" assumption and, in microeconomic theory, it ensures that the behaviour of property owners is in line and consistent with the behaviour that would necessarily emerge in a pure capitalistic system. Not surprisingly, "rationality" is recognised as a necessary assumption in Medema's recent reformulation of the "Coase theorem", next to transaction costs (Medema, 2017: 37). (And the rationality is also necessarily present to demonstrate the validity of the standard welfare theorems.) 
The joint employment of rationality and transaction costs can shed full light on the dual nature of property rights expressed in function of the three-dimensional framework developed above. The presence (and extent) of transaction costs remains the necessary and sufficient condition in order to explain and understand different property regimes only and exclusively for pure capitalistic systems, where the rationality assumption holds, and it is possible to assume that all properties will always be necessarily employed by their respective owners as capital, no matter what. In this case, value becomes a monism and corresponds to socially-objective exchange value. Outcomes, solutions and arrangements in this case can be legitimately be judged and evaluated in light of the common goal of maximization of the social (overall) wealth of the economic system.

In the case of a pure capitalistic economy, the intuitions of the modular (or informational) approach adopted by the new economics of property law become valuable, relevant, and legitimate: property rights assume a dual nature depending on the level of transaction costs. In the ideal case of zero transaction costs, property law in a capitalistic system disappears and collapses into contract (or tort) law, thus satisfying the considerations developed by the pure bundle of right approach.

Properties, however, may also be employed to serve values and purposes that are incommensurable and inconsistent with the capitalistic system. For instance, an individual may treat his property in order to fulfil non-monetary values, such as his own personal development or enjoyment, human flourishing, autonomy, moral virtues, mere self-subsistence, social inclusion, and so forth. These values can be moral, natural, social virtues, or merely subjective. In this case, a new normative dimension capturing the heterogeneity of different value judgments in the employment of properties has to be added and the basic two-dimensional framework becomes a full three-dimensional framework. There may be many non-welfarist interpretations of the normative dimension. Personal use is just one among many others. 
Whenever properties can also be employed as personal properties "in use", and not merely as capital "in exchange", legitimate normative conclusions on the "economic optimality" of a property regimes (and of an institutional setting in general) can only be derived if the possibility of these non-capitalistic value judgments are controlled for, and ruled out, so to make sure that the observed use of properties by the part of the individuals are in line with the behaviours that would have been expected in a pure capitalistic regime. The rationality assumption represents the necessary additional condition that legitimises and justifies the transition from the classical treatment of property rights to the neoclassical realm of capitalistic economies (more generally, it justifies the transition from any heterogeneous normative value judgment to the neoclassical homogeneous capitalistic value judgment). 


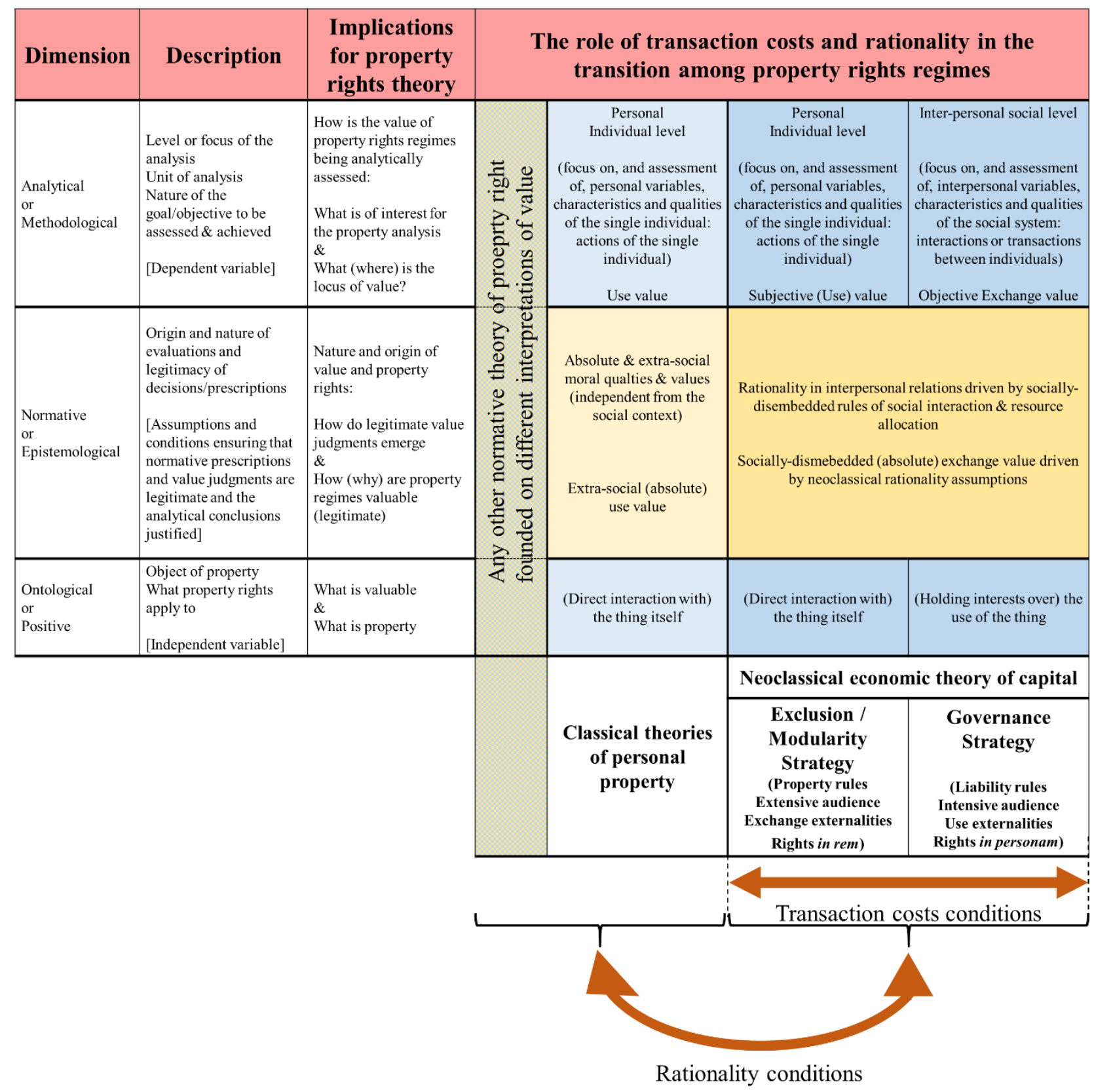

Figure 4 - Clarifying the role of transaction costs and rationality in the transition from classical theory of personal property to the neoclassical theory of capital

Two concluding observations follow from the discussion developed above.

First, it is interesting to note that any economic analysis of property right revolves around three different dimensions, which also map into three different categories and elements. The tripartite analysis of property rights, composed of analytical, normative and ontological dimensions is 
reflected into a trilateral framework composed of three core elements: transactions (costs), (economic) rationality, and properties, respectively. The rationality condition controls for the normative dimension, transaction (costs) controls for the analytical dimension, while the nature of properties belong to the ontological dimension of the system. When all three dimensions are taken into account and no specific dimension is "exogenously fixed" by assumption, all three elements play a role in defining and explaining the nature of a socio-political-moral system.

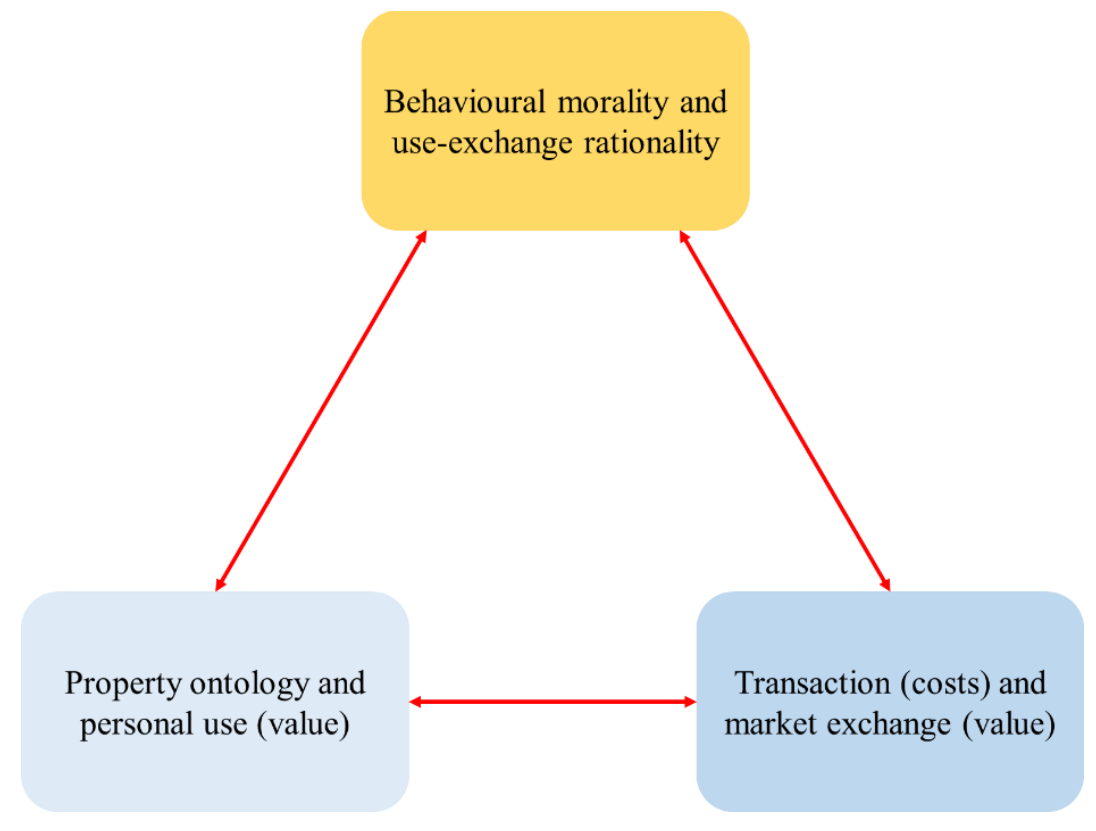

Figure 5 - From three-dimensional framework to the three elements of an economic analysis of property rights

This three-dimensional framework recalls Williamson's (1985: chapter 1) tripartite division between asset specificity (ontology of property), opportunism (behavioural or moral condition), and uncertainty (contextual analytical condition), with the fundamental distinction that Williamson only applies his framework to firms, thus assuming a de facto capitalistic system. This allows him to treat all three dimensions of his framework as different manifestations of positive transaction costs. 
Secondly, this interpretation of the rationality condition unveils a strict linkage between the meaning of rationality in neoclassical economics, the meaning of capital, and the nature of a capitalistic system: a "rational behaviour" in neoclassical economics characterises the behaviour of an individual that always employs his properties as if they were pure capital (thus always striving to maximise the monetary wealth deriving from personal properties). Vice versa, capital is any property employed consistent with the condition of neoclassical rationality, while a capitalistic system is an economic system characterised by the fact that all property owners employ their properties in line with neoclassical rationality.

This also implies that pure capitalistic systems are, by definition, always characterised by "full rationality": economic systems become capitalistic whenever individuals employ their properties in line with neoclassical rationality, while economic systems where individuals employ their properties in line with neoclassical rationality are necessarily capitalistic. In such a framework, a glitch in rationality is a glitch in the capitalistic nature of an economic system, and this most likely derives from an employment of properties in personal consumption, in line with classical property law, but in violation with the neoclassical precepts of property law. This is after all consistent with the findings of behavioural law and economics and behavioural studies in property right theories, especially with respect to the endowment effect (Kahneman et al., 1990), which is almost certainly a manifestation of the value-in-use of possession deriving from the possibility to disengage from the market mechanism, and to employ a property for personal consumption (Lewinsohn-Zamir, 2003, 2015; Stern and LewinsohnZamir, 2020: 21-48; see also Merrill, 2015b).

In sum, the problem with much law and economics and Coasean property rights theory derives from the misinterpretation of the strong normative assumptions that guarantee and justify the normative legitimacy of welfare economics and its prescriptions (and microeconomics in general). 
It is usually thought in the law and economics and Coasean literature that neoclassical microeconomic models are "use neutral” and goal-agnostic (Smith, 2009; 2011a, 2012b, 2013a, 2014b), consistent with an utilitarian interpretation of individuals' behaviours and decisions. The assumption is that "economic property rights" (economic decisions as represented by economic models) represent the "ability to freely exercise a choice" so that "if transaction costs are zero, then there is no behavioural distinction between legal and economic property rights" (Allen, 2015a: 712). This assumed behavioural neutrality (and moral agnosticism) is the supposed reason why it is possible to de-contextualise value as a socially-disembedded category, and to endow transaction cost with all the explanatory and normative power that the concept currently enjoys.

However, this interpretation of neoclassical microeconomic models is not quite correct and disregards the deep normative meaning hidden behind the assumptions of current welfare economics. Neoclassical microeconomics (and welfare economics) places very strict and clear constraints on the available set of actions that an economic actor is allowed to undertake. This constraints ensure that the behaviour of any individual is consistent with rational (or "rationalizable") utility functions that is, with monotone and convex surfaces. In this cases, dualisms can be treated as "dualities".

A better consideration of the normative assumptions linking the positive description of the model (ontological condition) and its analytical conclusions (analytical dimension) will reveal that neoclassical normative economics has ceased to be subjectivist and utilitarian since the 1930s (since the Slutsky-Hicks-Samuelson ordinalist revolution in welfare economics), that it is not use-neutral, value-agnostic, or context-independent, and that it is very far from assuming the free will of individuals, or leaving free choices to its economic actors (that is, the original philosophical foundations of property law and property rights themselves). Outside the "rational" capitalistic context, behaviours cannot be rationalised anymore, and the normative 
and predictive power of the discipline crumbles. An exclusion strategy is, mathematically speaking, a non-monotone strategy, which decouples the value-in-use of the property from its value-in-exchange.

These problems with the neoclassical welfarist interpretations of property rights (and legal institutions in general) has been raised multiple times by legal scholars (Alexander, 2011 \& 2014; Claeys, 2009, 2010, 2012; Dagan, 2012; Ripstein, 2013; Singer, 2014) and political economists (Hodgson, 2015a, 2015b), but without much success (see also Rossi, 2015).

This makes the normative power of transaction costs institutionally-determined, rather than institutional-determining. The old intuitions of legal realists, old progressive and institutional economists should be revaluated and reconsidered vis-à-vis the current dominance of (neoclassical or welfarist) new-institutional economics (beyond the role of transactions along the analytical dimension).

\section{Conclusion}

This paper provided a further contribution to the ongoing debate among legal scholars and economists on the nature and meaning of property rights and, especially, on the relationship between property rights and normative conclusions in law and economics. Contemporary developments in the legal and economic discipline have abandoned the old monistic and univocal interpretations of property rights and have recognised that property rights have a dual (or even plural) nature and that both dimensions of use (governance) and exclusion (exclusive dominium) should be considered in order to grasp the essence of property rights.

Nowadays the core of the debate is not really on whether property rights have a dual nature, but rather on how the two aspects of property should be conceptualised and linked to each other. This paper provides an historical reconstruction of the development of the concept of property rights from the roman and classical interpretation of property rights as exclusive 
(absolute) dominium over things, to the neoclassical interpretation of property rights as a bundle of interpersonal interests over the use of things, and shows that the transition from one school of thought to another one is usually developed along three different dimensions, each capturing a different aspects of a property rights theory.

Based on the decomposition of property rights into their three fundamental dimensions, the paper argues that one fundamental reason why property rights have been historically interpreted along two main lines (absolute dominium or bundle of use rights), and the dual nature of property right themselves, may simply derive from the fact that properties can be employed in two different ways: as personal properties or as capital (private property). Different theories have simply focussed on one aspect of properties or on the other, depending on their in different historical and socio-economic contexts. Once that the three dimensions are identified, the differences in theories become consistent with a different interpretation of properties and the divergence in approaches simply reflects a contextual difference in the specific and contingent problems faced by the different thinkers and authors.

By decomposing property right theories into three fundamental dimensions, and by showing that one way to reconcile these three dimensions (which is both historically accurate and logically consistent) is to interpret the dual nature of property rights in function of the dichotomy between personal property (property for personal use) and capital (property for interpersonal economic use), the paper makes two contributions to the current debates on property rights, which were mainly revived by Merrill and Smith's (2000, 2001a, 2001b, 2011) novel and very important contributions.

First, although the paper agrees with the critiques moved against the one-sided approach adopted by legal realist, old progressive and institutional economists, it also indirectly supports the essence of their argument, by linking the meaning and the nature of property rights to the 
specific social, political, cultural and technological context in which the concept is developed and studied. Whether a certain property is employed for personal use or for interpersonal monetary gain can only be understood and explained with respect to the specific technological, political, social, and cultural context in which these decisions are taken.

Second, the paper shows why reframing the dual nature of property rights as a dichotomy between personal property and capital clarifies the role of transaction costs in analysing and understanding legal institutions (and property right regimes). Coasean law and economics and neoclassical (welfarist) theories of property rights do internalise and acknowledge the dual nature of the problem, but fail to appreciate the role played by the normative dimension in shaping and defining this dualism.

The characterization of this dualism in terms of personal property and capital highlights the fact that the dual nature of property rights necessarily also entails a dualism in the normative foundations of evaluations and value judgments. The normative legitimacy of either side of the dualism cannot be understood independently from an underlying dualism in their respective normative (and moral) dimensions. Once that the dual nature of property rights is developed along all three dimensions (as in the case of the dichotomy between personal property and capital), it becomes clear that legal regimes cannot be understood and analysed exclusively in function of the sole concept of transaction cost, and that some additional assumption is needed in order to explain why a property is employed for one's personal enjoyment, rather than as capital in order to generate wealth and increase overall social welfare (and vice versa).

As a result, the work shows that any economic theory of legal institutions has a threedimensional nature and, as a result, always necessarily stands on three legs: an ontological or positive definition of the "legal entity" considered (what is the object of analysis, and its characteristics), analytical and methodological assumptions on the locus of analysis and its 
characteristics (transactions and its characteristics, including its "costs"), and normative assumptions on the way in which value is defined, and value judgments emerge and are derived (rationality and its behavioural constraints). All these three dimensions always necessarily play a role in the definition and characterization of the dual (or even plural) nature of property rights.

\section{References}

Alexander, G. S. (1997). Commodity \& Propriety: Competing Visions of Property in American Legal Thought, 1776-1970: University of Chicago Press.

Alexander, G. S. (1998). Property as Propriety. Neb. L. Rev., 77, 667.

Alexander, G. S. (2009a). The social-obligation norm in American property law. Cornell L. Rev., 94, 745 .

Alexander, G. S. (2009b). The Complex Core of Property. Cornell L. Rev., 94, 1063.

Alexander, G. S. (2011). Pluralism and property. Fordham L. Rev., 80, 1017.

Alexander, G. S. (2014). Property's Ends: The Publicness of Private Law Values. Iowa L. Rev., 99, 1257.

Alexander, G. S. (2018). Property and human flourishing. Oxford University Press.

Alexander, G., \& Peñalver, E. (2008). Properties of Community, Theoretical Inquiries in Law, $10(1), 127-160$.

Alexander, G. S., \& Peñalver, E. M. (2012). An introduction to property theory: Cambridge University Press.

Alexander, G. S., Peñalver, E. M., Singer, J. W., \& Underkuffler, L. S. (2009). A statement of progressive property. Cornell L. Rev., 94, 743.

Allen, D.W. (2000), 'Transaction Cost', in B. Bouckaert and G. Geest (ed.) Encyclopedia of Law and Economics, Volume 1, Cheltenham: Edward Elgar, pp. 893-926.

Allen, D.W. (2015a), On Hodgson on property rights. Journal of Institutional Economics, 11(4), 711-717.

Allen, D. W. (2015b). The Coase theorem: coherent, logical, and not disproved. Journal of Institutional Economics, 11(2), 379-390.

Allen, D. W. (2017). Property as sequential exchange: definition and language issues. Journal of Institutional Economics, 13(4), 785-792.

Aloni, E. (2018), Pluralism and regulatory response to the sharing economy. Cambridge Handbook on Law and Regulation of the Sharing Economy, Cambridge: Cambridge University Press. 
Aoki, M., (2001). Toward a comparative institutional analysis. MIT press.

Arrow, K. J. (1987), "Reflections on the Essays," in G. Feiwel (ed.) Arrow and the Foundations of the Theory of Economic Policy.. NY: NYU Press, pp. 727-34.

Arrow, K. J., \& Debreu, G. (1954). Existence of an equilibrium for a competitive economy. Econometrica, 22, 3: 265-290.

Arruñada, B. (2003). Property enforcement as organized consent. Journal of Law, Economics, and Organization, 19(2), 401-444.

Arruñada, B. (2012a). Property as an economic concept: reconciling legal and economic conceptions of property rights in a Coasean framework. International Review of Economics, 59(2), 121-144.

Arruñada, B. (2012b). Institutional foundations of impersonal exchange: Theory and policy of contractual registries: University of Chicago Press.

Arruñada, B. (2015). The titling role of possession. The Law and Economics of Possession, 207-233.

Arruñada, B. (2016). Coase and the Departure from Property. In The Elgar companion to Ronald H. Coase: Edward Elgar Publishing.

Arruñada, B. (2017a). Property as sequential exchange: the forgotten limits of private contract. Journal of Institutional Economics, 13(4), 753-783.

Arruñada, B. (2017b). How should we model property? Thinking with my critics. Journal of Institutional Economics, 13(4), 815-827.

Baron, J. B. (2009). The contested commitments of property. Hastings LJ, 61, 917.

Baron, J. B. (2013). Rescuing the bundle-of-rights metaphor in property law. U. Cin. L. Rev., $82,57$.

Barzel, Y. (1997). Economic analysis of property rights: Cambridge university press.

Barzel, Y. (2015). What are 'property rights', and why do they matter? A comment on Hodgson's article. Journal of Institutional Economics, 11(4), 719-723.

Bell, A., \& Parchomovsky, G. (2004). A Theory of Property. Cornell Law Review (3), 531616.

Berger, L. (1995). Public Use, Substantive Due Process and Takings-An Integration. Neb. L. Rev., 74, 843.

Berle, A. A., \& Means, G. G. C. (1991 [1932]). The Modern Corporation and Private Property: Transaction Publishers.

Blackstone, W. (1825). Commentaries on the Law of England. Book the Fourth. The 16-th edition.--London: A. Strahan and J. In: Butterworth and Son.

Blaug, M. (2003). The formalist revolution of the 1950s. Journal of the History of Economic Thought, 25(2), 145-156. 
Bouckaert, B. (1990). What is property. Harv. JL \& Pub. Pol'y, 13, 775.

Buckle, S. (1991). Natural law and the theory of property: Grotius to Hume, Oxford university Press.

Calabresi, G., \& Melamed, A. D. (1972). Property rules, liability rules, and inalienability: one view of the cathedral, Harvard Law Review, Vol. 85, No. 6, pp. 1089-1128

Chang, Y. C. (Ed.). (2015). Law and economics of possession. Cambridge: Cambridge University Press.

Chang, Y.-c., \& Smith, H. E. (2012). An economic analysis of civil versus common law property. Notre Dame L. Rev., 88, 1 .

Chang, Y.-c., \& Smith, H. E. (2014). The Numerus Clausus Principle, Property Customs, and the Emergency of New Property Forms. Iowa L. Rev., 100, 2275.

Claeys, E. R. (2009a). Property 101: Is property thing or bundle? Seattle University Law Review, 32(3), 617-650.

Claeys, E. R. (2009b). Virtue and Rights in American Property Law. Cornell L. Rev., 94, 889.

Claeys, E. R. (2010). Jefferson meets coase: Land-use torts, law and economics, and natural property rights. Notre Dame Law Review , 85(4), 1379-1446.

Claeys, E. R. (2011). Bundle-of-sticks notions in legal and economic scholarship. Econ Journal Watch, Vol. 8, No. 3, 205-214

Claeys, E. R. (2012). Exclusion and Legal Theory: A Comment on Property as the Law of Things: George Mason University School of Law.

Claeys, E. R. (2017). Labor, exclusion, and flourishing in property law. North Carolina Law Review, 95(2), 413-492.

Claeys, E. R. (2019). Property, concepts, and functions. Boston College Law Review, 60(1), 172.

Coase, R. H. (1937), “The Nature of the Firm.” Economica, 4(16): 386-405.

Coase, R. H. (1960), “The Problem of Social Cost.” Journal of Law and Economics, 3(1): 144.

Cohen, F. S. (1935). Transcendental nonsense and the functional approach. Colum. L. Rev., 35, 809-49.

Cohen, F. S. (1954). Dialogue on Private Property, Rutgers Law Review, 9: 357.

Cohen, M. R. (1927). Property and Sovereignty. Cornell Law Quarterly (1), 8-30.

Cole, D. H. (2015). 'Economic property rights' as 'nonsense upon stilts': a comment on Hodgson. Journal of Institutional Economics, 11(4), 725-730.

Commons, J. R. (1893). The distribution of wealth, Macmillan and Company.

Commons, J. R. (1924), Legal foundations of capitalism, New Yor: McMillan. 
Commons, J. R. (1931). Institutional Economics. The American Economic Review, 21(4), 648657.

Commons, John R. 1932. "The Problem of Correlating Law, Economics, and Ethics." Wisconsin Law Review, 8: 3-26.

Corbin, A. L. (1912). Quasi-contractual obligations. The Yale Law Journal, 21(7), 533-554.

Corbin, A. (1922). Taxation of seats on the stock exchange. Yale Law Journal, 429-431.

Corbin, A. L. (1952). Corbin on contracts: West Pub. Co.

Cornes, R. (1992), Duality and Modern Economics, Cambridge: Cambridge University Press.

d'Entreves, A. P. (2017 [1951]). Natural law: An introduction to legal philosophy: Routledge.

Dagan, H. (2003). The craft of property. Calif. L. Rev., 91, 1517.

Dagan, H. (2009). Exclusion and Inclusion in Property. Available at SSRN 1416580.

Dagan, H. (2011). Property: values and institutions: Oxford University Press.

Dagan, H. (2012). Pluralism and Perfectionism in Private Law. Colum. L. Rev., 112, 1409.

Dagan, H. (2013a). Inside Property. University of Toronto Law Journal, 63(1), 1-21.

Dagan, H. (2013b). Reconstructing American legal realism \& rethinking private law theory. Oxford University Press.

Dagan, H. (2014a). Doctrinal categories, legal realism, and the rule of law. U. Pa. L. Rev., 163, 1889.

Dagan, H. (2014b). Property Structural Pluralism: On Autonomy, the Rule of Law, and the Role of Blackstonian Ownership, Brigham-Kanner Prop. Rts. Conf. J. (Vol. 3, p. 27).

Dagan, H., \& Heller, M. (2005). Conflicts in Property. Theoretical Inquiries in Law, 6(1), $37-$ 58.

Debreu, G. (1959). Theory of value: An axiomatic analysis of economic equilibrium (No. 17). Yale University Press.

Demsetz, H. (1967). Towards a Theory of Property Rights. The American Economic Review, 57(2), 347-359.

Di Robilant, A. (2013). Property: a bundle of sticks or a tree. Vand. L. Rev., 66, 869.

Douglas, S., \& McFarlane, B. (2013). Defining property rights, in J. Penner and H. Smith (Eds.), Philosophical Foundations of Property Law, 220-243.

Dunn, J. (1982 [1969]). The Political Thought of John Locke: An historical account of the argument of the 'Two Treatises of Government'. Cambridge University Press.

Dyal-Chand, R. (2010). Useless Property. Cardozo L. Rev., 32, 1369.

Dyal-Chand, R. (2013). Sharing the Cathedral. Conn. L. Rev., 46, 647.

Ellickson, R. C. (2011). Two cheers for the bundle-of-sticks metaphor, three cheers for Merrill and Smith. Econ Journal Watch, 8(3), 215. 
Ellickson, R. C. (2014). The Affirmative Duties of Property Owners: An Essay for Tom Merrill. In Brigham-Kanner Prop. Rts. Conf. J. (Vol. 3, p. 43).

Ely, R.T. (1899), Political Economy. In Political Economy, Political Science and Sociology, ed. Richard T. Ely. Chicago: University Association

Ely, R. T. (1914). Property and Contract in their Relations to the Distribution of Wealth (Vol. 1): Macmillan.

Ely, J. (1999). The oxymoron reconsidered: Myth and reality in the origins of substantive due process. Constitutional Commentary, 16(2), 315-346.

Epstein, R. A. (1979). Possession as the Root of Title Perspectives on Rights. Georgia Law Review(4), 1221-1244.

Epstein, R. A. (1985). Takings: Private property and the power of eminent domain: Harvard University Press.

Epstein, R. A. (2011). Bundle-of-Rights Theory as a Bulwark Against Statist Conceptions of Private Property. Econ Journal Watch, 8(3).

Fiorito, L., \& Vatiero, M. (2011). Beyond Legal Relations: Wesley Newcomb Hohfeld's Influence on American Institutionalism. Journal of Economic Issues, 45(1), 199-222.

Foss, K., \& Foss, N. (2001). Assets, attributes and ownership. International Journal of the Economics of Business, 8(1), 19-37.

Fried, B. (2009). The progressive assault on laissez faire: Harvard University Press.

Garegnani, P. (1984). Value and distribution in the classical economists and Marx. Oxford economic papers, 36(2), 291-325.

Gilmore, G. (1961). Legal realism: Its cause and cure. The Yale Law Journal, 70(7), 10371048 .

Greif, A. (1998). Historical and comparative institutional analysis. The American Economic Review, 88(2), 80-84.

Grey, T. C. (1980). The disintegration of property. Nomos, 22, 69-85.

Haakonssen, K., \& Knud, H. (1996). Natural law and moral philosophy: from Grotius to the Scottish Enlightenment: Cambridge University Press.

Hale, R. L. (1922). Rate Making and the Revision of the Property Concept. Columbia Law Review, 22(3), 209-216.

Hale, R. L. (1923). Coercion and distribution in a supposedly non-coercive state. Political Science Quarterly, 38(3), 470-494.

Harris, J. W. (1996). Property and justice: OUP Oxford.

Hart, O. (1995). Firms, contracts, and financial structure.

Hart, O., \& Moore, J. (1999). Foundations of incomplete contracts. The Review of Economic Studies, 66(1), 115-138. 
Heydt, C. (2017). Moral philosophy in eighteenth-century Britain: God, self, and other: Cambridge University Press.

Hippler, T. A. (1986). Reexamining 100 Years of Supreme Court Regulatory Taking Doctrine: The Principles of Noxious Use, Average Reciprocity of Advantage, and Bundle of Rights from Mugler to Keystone Bituminous Coal. BC Envtl. Aff. L. Rev., 14, 653.

Hodgson, G. M. (2003). John R. Commons and the foundations of institutional economics. Journal of Economic Issues, 37(3), 547-576.

Hodgson, G. M. (2009). On the institutional foundations of law: the insufficiency of custom and private ordering. Journal of Economic Issues, 43(1), 143-166.

Hodgson, G. M. (2014). What is capital? Economists and sociologists have changed its meaning: should it be changed back? Cambridge Journal of Economics, 38(5), 10631086.

Hodgson, G. M. (2015a). Much of the 'economics of property rights' devalues property and legal rights. Journal of Institutional Economics, 11(4), 683-709.

Hodgson, G. M. (2015b). What Humpty Dumpty might have said about property rights-and the need to put them back together again: a response to critics. Journal of Institutional Economics, 11(4), 731-747.

Hodgson, G. M. (2015c). Conceptualizing capitalism: Institutions, evolution, future. University of Chicago Press.

Hohfeld, W. N. (1913). Some fundamental legal conceptions as applied in judicial reasoning. Yale $\mathrm{Lj}, 23,16$.

Hohfeld, W. N. (1917). Fundamental legal conceptions as applied in judicial reasoning. The Yale Law Journal, 26(8), 710-770.

Horwitz, M. J. (1973). The Transformation in the Conception of Property in American Law, 1780-1860. The University of Chicago Law Review, 40(2), 248-290.

Horwitz, M. J. (1992). The transformation of American law, 1870-1960: The crisis of legal orthodoxy: Oxford University Press.

Hovenkamp, H. (1988a). The political economy of substantive due process. Stanford Law Review, 40(2), 379-448.

Hovenkamp, H. (1988b). Regulatory conflict in the gilded age: Federalism and the railroad problem. Yale Law Journal, 97(6), 1017-1072.

Hovenkamp, H. (1989). The Sherman act and the classical theory of competition. Iowa Law Review, 74(5), 1019-1066.

Hovenkamp, H. (1991). Enterprise and American law, 1836-1937.

Johnson, D. R. (2007). Reflections on the Bundle of Rights. Vt. L. Rev., 32, 247.

Kahneman, D., Knetsch, J. L., \& Thaler, R. H. (1990). Experimental tests of the endowment effect and the Coase theorem. Journal of political Economy, 98(6), 1325-1348. 
Kainen, J. L. (1982). Nineteenth century interpretations of the federal contract clause: The transformation from vested to substantive rights against the state. Buffalo Law Review, 31(2), 381-480.

Kainen, J. L. (1993). Historical framework for reviving constitutional protection for property and contract rights Cornell Law Review, 79(1), 87-142.

Kalman, L. (2016). Legal realism at Yale, 1927-1960: UNC Press Books.

Kaplow, L., \& Shavell, S. (2003). Fairness versus welfare: notes on the Pareto principle, preferences, and distributive justice. The Journal of Legal Studies, 32(1), 331-362.

Kaplow, L., \& Shavell, S. (2009). Fairness versus welfare: Harvard university press.

Katz, L. M. (2011). The Regulative Function of Property Rights. Econ Journal Watch, 8(3), 236-246.

Katz, L., (2018), Legal Forms in Property Law Theory, in J. Penner and M. Otsuka (Eds.), Property theory Legal and Political Perspectives, Cambridge Press, pp: 23-37.

Kennedy, D. (2006 [1980]). The Rise \& Fall of Classical Legal Thought. Beard Books.

Klein, D. B., \& Robinson, J. (2011). Property: A bundle of rights? Prologue to the property symposium. Econ Journal Watch, 8(3), 193.

Kobach, K. W. (1996). The Origins of Regulatory Takings: Setting the Record Straight. Utah L. Rev., 1211.

Kreiczer-Levy, S. (2015). Consumption property in the sharing economy. Pepp. L. Rev., 43, 61.

Kreiczer-Levy, S. (2017). Share, own, access. Yale L. \& Pol'y Rev., 36, 155.

Kreiczer-Levy, S. (2019). Destabilized Property: Property Law in the Sharing Economy. Cambridge University Press.

Larkin Jr, P. J. (2016). The Original Understanding of Property in the Constitution. Marq. L. Rev., 100, 1-80.

Lee, B. A., \& Smith, H. E. (2012). The nature of Coasean property. International Review of Economics, 59(2), 145-155.

Leiter, B. (1997). Rethinking legal realism: Toward a naturalized jurisprudence. Tex. L. Rev., 76, 267.

Lewinsohn-Zamir, D. (2003). The objectivity of well-being and the objectives of property law. NYUL rev., 78, 1669.

Lewinsohn-Zamir, D. (2015). What behavioral studies can teach jurists about possession and vice versa, in Yun-Chien chang (ed.) Law and Economics of Possession. Cambridge: Cambridge university press, pp: 128-148.

Llewellyn, K. N. (1930). What Price Contract--An Essay in Perspective. Yale Lj, 40, 704.

Llewellyn, K. N. (1937). Through Title to Contract and a Bit Beyond. NYULQ Rev., 15, 159. 
Locke, J. (1967). Locke: Two treatises of government: Cambridge University Press.

Locklin, D. P. (1933). The literature on railway rate theory. The Quarterly Journal of Economics, 47(2), 167-230.

Lueck, D. (2017). Property institutions and the limits of Coase. Journal of Institutional Economics, 13(4), 793-800.

Lueck, D., \& Miceli, T. J. (2007). Chapter 3 Property Law. In A. M. Polinsky \& S. Shavell (Eds.), Handbook of Law and Economics (Vol. 1, pp. 183-257): Elsevier.

Macpherson, C. B. (2011 [1962]). The political theory of possessive individualism: Hobbes to Locke, Oxford U.P.

Maloney, J. P. (1937). Restatement of the Law of Property. John's L. Rev., 12, 1.

Mas-Colell, A., Whinston, M. D., \& Green, J. R. (1995). Microeconomic theory (Vol. 1). New York: Oxford university press.

Maskin, E., \& Tirole, J. (1999). Unforeseen contingencies and incomplete contracts. The Review of Economic Studies, 66(1), 83-114.

Mayer, D. N. (2009). The myth of laissez-faire constitutionalism: Liberty of contract during the lochner era. Hastings Constitutional Law Quarterly, 36(2), 217-284.

McCurdy, C. W. (1975). Justice Field and the jurisprudence of government-business relations: Some parameters of laissez-faire constitutionalism, 1863-1897. The Journal of American History, 61(4), 970-1005.

Medema, S. G. (2017). The Coase theorem at sixty. Working paper, University of Colorado

Medema,S. and Zerbe (2000), 'The Coase Theorem', in B. Bouckaert and G. Geest (Eds.), Encyclopedia of Law and Economics, Cheltenham: Edward Elgar, Volume 1, pp: 836891

Ménard, C. (2017). What approach to property rights? Journal of Institutional Economics, 13(4), 801-807.

Menger, C. (1981 [1871]), Principles of Economics, New York: NYU Press.

Merrill, T. W. (1998). Property and the Right to Exclude. Neb. L. Rev., 77, 730.

Merrill, T. W. (2011a). Property as modularity. Harv. L. Rev. F., 125, 151.

Merrill, T. W. (2011b). The property prism. Econ Journal Watch, 8(3), 247.

Merrill, T. W. (2014). Property and the Right to Exclude II. In Brigham-Kanner Prop. Rts. Conf. J. (Vol. 3, p. 1).

Merrill, T. W. (2015a). Ownership and possession. Law and Economics of Possession, 1-39.

Merrill, T. W. (2015b). Possession as a Natural Right. NYUJL \& Liberty, 9, 345.

Merrill, T. W., \& Smith, H. E. (2000). Optimal standardization in the law of property: the numerus clausus principle. The Yale Law Journal, 110(1), 1-70. 
Merrill, T. W. (2017). Property and Sovereignty, Information and Audience. Theoretical Inquiries in Law, 18(2), 417-445.

Merrill, T. W., \& Smith, H. E. (2001a). The property/contract interface. Columbia Law Review, 773-852.

Merrill, T. W., \& Smith, H. E. (2001b). What happened to property in law and economics. Yale Lj, 111, 357 .

Merrill, T. W., \& Smith, H. E. (2011). Making Coasean Property More Coasean. The journal of Law and Economics, 54(S4), S77-S104.

Merrill, T.W., and Smith, H. (2019), The Architecture of Property, Forthcoming in Hanoch Dagan and Benjamin Zipursky (eds.), Research Handbook on Private Law Theories..

Mossoff, A. (2003). What is property-putting the pieces back together. Ariz. L. Rev., 45, 371.

Mossoff, A. (2011). The False Promise of the Right to Exclude. Econ Journal Watch, 8(3), 255-264.

Munzer, S. R. (2011). A bundle theorist holds on to his collection of sticks. Econ Journal Watch, 8(3), 265-73.

Munzer, S. (2013), Property and Disagreement, in Penner and H. Smith (Eds.), Phylosophical Foundations of Property Law, Oxford U.P., pp. 289- 319.

Nachbar, T. B. (2016). The Rationality of Rational Basis Review. Va. L. Rev., 102, 1627.

Newman, C. M. (2018). Using things, defining property, in J. Penner and M. Otsuka (eds.) Property Theory: Legal and Political Perspectives, pp: 69-98.

Nichols. (1949). The Public Use Limitation of Eminent Domain: An Advance Requiem. Yale $L j, 58,599$.

Olivecrona, K. (1974a). Appropriation in the State of Nature: Locke on the Origin of Property. Journal of the History of Ideas, 211-230.

Olivecrona, K. (1974b). Locke's theory of appropriation. The Philosophical Quarterly(1950-), 24(96), 220-234.

Penalver, E. M. (2009). Land virtues. Cornell L. Rev., 94, 821.

Penner, J. J. (1996). The bundle of rights picture of property. UCLA Law Review, 43(3), 711820.

Penner, J. E. (1997). The idea of property in law: Oxford University Press.

Penner, J. E. (2011). Potentiality, Actuality, and" Stick"-Theory. Econ Journal Watch, 8(3), 274.

Penner, J., \& Otsuka, M. (Eds.). (2018). Property Theory: Legal and Political Perspectives. Cambridge University Press.

Penner, J., \& Smith, H. (Eds.). (2013). Philosophical foundations of property law. OUP Oxford. 
Pound, R. (1982 [1933]), Legal Philosophy in America, in M.R. Cohen (ed.) "Law and the Social Order: Essays in Legal philosophy" (1982 [1933]), London, Transaction Books, p: 327

Philbrick, F. S. (1938). Changing conceptions of property in law. University of Pennsylvania Law Review and American Law Register, 86(7), 691-732.

Purdy, J. (2009). A Few Questions About the Social-Obligation Norm. Cornell L. Rev., 94, 949.

Radin, M. J. (1982). Property and personhood. Stanford Law Review, 957-1015.

Radin, M. J. (1986). Time, possession, and alienation. Wash. ULQ, 64, 739.

Radin, M. J. (1987). Market-inalienability. Harvard Law Review, 1849-1937.

Radin, M. J. (1996). Contested commodities: Harvard University Press.

Reich, C. A. (1964). The New Property. The Yale Law Journal, 73(5), 733-787.

Ricardo, D. (1971 [1821]), the the principles of Poliical Economy and Taxation, Harmondsworth : Penguin

Ripstein, A. (2013). Possession and use, in J. Penner and H. Smith (eds.), Philosophical Foundations of Property Law, 156-181.

Robbins, L. (1935), An essay on the nature and significance of economic science ( $2^{\text {nd }}$ ed.), London: Macmillan.

Rose, C. M. (1985). Possession as the Origin of Property. The University of Chicago Law Review, 52(1), 73-88.

Rose, C. M. (1998). Canons of property talk, or, Blackstone's anxiety. The Yale Law Journal, 108(3), 601-632.

Rosser, E. (2013). The ambition and transformative potential of progressive property. California Law Review, 107-171.

Rosser, E. (2015). Destabilizing property. Conn. L. Rev., 48, 397.

Rossi, E. (2015). The institutional structure of production revisited. Journal of Institutional Economics, 11(2), 301-327.

Samuelson, P. (1947), Foundations of Economic Analysis, Cambridge, (Mass.): Harvard University Press.

Savin, M. D., \& Clarke, S. J. (2014). Lost Visibility and the Right to Exclude: How Merrill's Sine Qua Non of Property Compels Just Compensation in Takings Cases. In BrighamKanner Prop. Rts. Conf. J. (Vol. 3, p. 71).

Schlegel, J. H. (1978). American legal realism and empirical social science: From the Yale experience. Buff. L. Rev., 28, 459.

Schneewind, J. B. (1998). The invention of autonomy: A history of modern moral philosophy: Cambridge University Press. 
Seligman, E.R.A. (1887), Railway Tariffs and the Inerstate Commerce Law, Political Science Quarterly, Vol. 2, No. 2, 223-264

Shavell, S. (2009). Foundations of economic analysis of law: Harvard University Press.

Siegel, S. A. (1986). Understanding the Nineteenth Century Contract Clause: The Role of the Property-Privilege Distinction and Takings Clause Jurisprudence. S. Cal. L. Rev., 60, 1.

Siegel, S. A. (1991). Lochner Era Jurisprudence and the American Constitutional Tradition. NCL Rev., 70, 1.

Singer, J. W. (1982). The legal rights debate in analytical jurisprudence from Bentham to Hohfeld. Wis. L. Rev., 975.

Singer, J. W. (1988a). Legal realism now. Calif. L. Rev., 76, 465.

Singer, J. W. (1988b). The reliance interest in property. Stanford Law Review, 611-751.

Singer, J. W. (2009). Democratic estates: Property law in a free and democratic society. Cornell L. Rev., 94, 1009.

Singer, J. (2013). The rule of reason in property law. U.C. Davis Law Review, 46(5), 13691434.

Singer, J. W. (2014). Property as the Law of Democracy. Duke Law Journal, 1287-1335.

Smith, A. (1970 [1776]), The Wealth of Nations, Harmondsworth: Penguin

Smith, H. E. (2002). Exclusion versus governance: Two strategies for delineating property rights. The Journal of Legal Studies, 31(S2), S453-S487.

Smith, H. E. (2003). The language of property: Form, context, and audience. Stanford Law Review, 1105-1191.

Smith, H. E. (2004a). Exclusion and property rules in the law of nuisance. Virginia Law Review, 965-1049.

Smith, H. E. (2004b). Property and property rules. NYUL rev., 79, 1719.

Smith, H. E. (2005). Self-help and the nature of property. JL Econ. \& Pol'y, 1, 69.

Smith, H. E. (2009a). Mind the gap: the indirect relation between ends and means in American property law. Cornell L. Rev., 94, 959.

Smith, H. E. (2009b). Law and economics: Realism or democracy. Harv. JL \& Pub. Pol'y, 32, 127.

Smith, H. E. (2011a). Toward an economic theory of property in information. Research Handbook on the Economics of Property Law, 104.

Smith, H. E. (2011b). Property is not just a bundle of rights. Econ Journal Watch, 8(3), 279291.

Smith, H. E. (2011c). Standardization in property law. Research Handbook on the Economics of Property Law, Cheltenham, UK and Northampton, MA, USA: Edward Elgar, 148-173.

Smith, H. E. (2012a). Property as the Law of Things. Harvard Law Review, 125(7), 1691-1726. 
Smith, H. E. (2012b). On the economy of concepts in property. University of Pennsylvania Law Review, 2097-2128.

Smith, H.E., (2013a), Emergent Property, in J. Penner and H.E. SMith (Eds.), Phylosophycal Foundations of Property Law, Oxford U.P., pp: 320-338.

Smith, H. E. (2013b). Property as Platform: Coordinating Standards for Technological Innovation. Journal of Competition Law and Economics, 9(4), 1057-1089.

Smith, H. E. (2014a). The thing about exclusion. In Brigham-Kanner Prop. Rts. Conf. J. (Vol. 3, p. 95).

Smith, H. E. (2014b). The Persistence of System in Property Law. U. Pa. L. Rev., 163, 2055.

Smith, H. E. (2015). The elements of possession. Law and Economics of Possession, 65-102.

Smith, H. E. (2017a). The Economics of Property Law, in F. Parisi (Ed.) The Oxford Handbook of Property law, pp: 148-177.

Smith, H. E. (2017b). Property as complex interaction. Journal of Institutional Economics, $13(4), 809-814$.

Stern, J. Y. (2018). What Is the Right to Exclude and Why Does It Matter? Property Theory: Legal and Political Perspectives (MH Otsuka \& JE Penner eds., Cambridge University Press 2018), pp: 38-68.

Stern, S. M., \& Lewinsohn-Zamir, D. (2020). The Psychology of Property Law.

Stigler, G. (1966), The Theory of Price ( $3^{\text {rd }}$ ed.), New York: Macmillan

Taussig, F. W. (1891). A contribution to the theory of railway rates, The Quarterly Journal of Economics, Vol. 5, No. 4, 438-465.

Tirole, J. (1999). Incomplete contracts: Where do we stand? Econometrica, 67(4), 741-781.

Tuck, R. (1979). Natural rights theories: their origin and development: Cambridge University Press.

Tully, J. (1980). A discourse on property: John Locke and his adversaries. Cambridge University Press.

Vandevelde, K. J. (1980). The new property of the nineteenth century: The development of the modern concept of property. Buff. L. Rev., 29, 325.

Waldron, J. (1988). The right to private property, Oxford

Waldron, J. (2002). God, Locke, and equality: Christian foundations in Locke's political thought: Cambridge University Press.

White, G. E. (1972). From sociological jurisprudence to realism: Jurisprudence and social change in early twentieth-century America. Va. L. Rev., 58, 999.

Wiecek, W. M. (1998). The Lost World of Classical Legal Thought: Law and Ideology in America, 1886-1937: Oxford University Press on Demand. 
Williams, R. C. (2010). The one and only substantive due process clause. The Yale Law Journal, 408-512.

Williamson, O. E. (1985), The Economic Institutions of Capitalism, New York: Free Press.

Williamson, O. E. (1991). Comparative economic organization: The analysis of discrete structural alternatives. Administrative science quarterly, 269-296.

Williamson, O. E. (1998). The institutions of governance. The American Economic Review, $88(2), 75-79$.

Williamson, O. E. (2000). The new institutional economics: taking stock, looking ahead. Journal of economic literature, 38(3), 595-613.

Williamson, O. E. (2002a). The lens of contract: private ordering. American Economic Review, 92(2), 438-443.

Williamson, O. E. (2002b). The theory of the firm as governance structure: from choice to contract. Journal of Economic Perspectives, 16(3), 171-195.

Williamson, O. E. (2010). Transaction cost economics: The natural progression. American Economic Review, 100(3), 673-690.

Wyman, K. M. (2008). Should Property Scholars Embrace Virtue Ethics-A Skeptical Comment. Cornell L. Rev., 94, 991.

Wyman, K. M. (2017). The New Essentialism in Property. Journal of Legal Analysis, 9(2), 183-246. 